\title{
Seasonal and spatial variability of coccolithophore export production at the South-Western margin of Crete (Eastern Mediterranean)
}

\author{
E. Malinvernoa, , , M.V. Triantaphylloub, S. Stavrakakisc, P. Ziverid, e, V. Lykousisc
}

a Department of Geological Sciences and Geotechnologies, University of Milano-Bicocca, Milano, Italy

b Department of Historical Geology-Paleontology, Faculty of Geology \& Geoenvironment, University of Athens, Athens, Greece

c Hellenic Centre for Marine Research (HCMR), Athens, Greece

d Institute of Environmental Science and Technology (ICTA), Autonomous University of Barcelona (UAB), Barcelona, Spain

e Department of Paleoclimatology, FALW, Vrije Universiteit Amsterdam, The Netherlands

Received 26 September 2008. Revised 18 February 2009. Accepted 20 February 2009. Available

online 11 March 2009.

http://dx.doi.org/10.1016/j.marmicro.2009.02.002, How to Cite or Link Using DOI

Cited by in Scopus (3)

Permissions \& Reprints

Abstract

Six moorings were deployed at different locations in the deep submarine canyons along the southwest margin of Crete, providing a total of eight sediment-trap time series from June 2005 to May 2006. Within this dataset, we analyzed the record from intact coccospheres, which represent the signal of export production from the coccolithophore community. The most abundant species at all stations during the whole investigated period were E. huxleyi and A. robusta, followed by S. pulchra HET, G. flabellatus, H. carteri, F. profunda, S. pulchra HOL oblonga, while the rest of the species represented $\leq 1 \%$ of the assemblage. Overall the assemblage composition was comparable at all stations, with slight variations mostly related to the different preservation of coccosphere integrity at the different collection depths. The consistent pattern of seasonal variation in species distribution and total coccolithophore export allowed us to define the occurrence of three main periods: a) March to June, with high overall coccosphere flux (up to $4.3 \times 105-3.4 \times 106$ coccospheres $m-2$ day -1 ), increased abundance of $E$. huxleyi and subordinate H. carteri s.s., Umbilicosphaera spp. and S. pulchra; b) June to November, with high but gradually decreasing total coccosphere flux (up to $7 \times 105-1.4 \times 106$ coccospheres $\mathrm{m}-2$ day- 1 ) and high relative abundance of the deep photic zone species A. robusta, F. profunda, G. flabellatus as well as S. pulchra and Coronosphaera spp., R. clavigera, U. tenuis, D. tubifera and holococcolithophores; c) November to February, with low overall export fluxes (3.5-9 $\times 104$ coccospheres $\mathrm{m}-2$ day -1$)$ and high relative abundance of A. robusta, S. pulchra and Syracosphaera spp. These three periods correspond to the seasonal changes in sea surface temperature, surface mixed layer depth and rainfall and are associated with varying total surface primary production, as detected through remote sensing in the surface waters.

\section{Keywords}

Coccolithophores; South-western Cretan margin; Sediment-traps; Seasonality

\section{Introduction}

Coccolithophores are the main planktonic calcifiers in the eastern Mediterranean ( [Knappertsbusch, 1993], [Ziveri et al., 2000a], [Ziveri et al., 2000b], [Malinverno et al., 2003a], [Malinverno et al., 2003b] and [Triantaphyllou et al., 2004]) and a major contributor to biogenic particle export production on a seasonal basis. Coccoliths are indeed the dominant biogenic component of settling particles in the deep Cretan Sea (Stavrakakis et al., 2000). Coccolithophore communities prove to be particularly sensitive to the seasonally varying oceanographic and environmental conditions of the upper water column. In fact some opportunistic species respond with a significant increase in their abundance and hence export production to the fertilization occurring during intervals of deep 
water mixing and/or external nutrient input (Ziveri and Thunell, 2000). Moreover, coccolithophore species include a deep community, which thrives in poorly illuminated but nutrient-rich waters below the seasonal thermocline. These species are partly responsible for the maintenance of a deep chlorophyll maximum, which is a characteristic feature throughout the oligotrophic eastern Mediterranean (Georgopoulos et al., 2000).

This is the first study of coccolithophore communities in the oligotrophic south Cretan margin. It is based on the record from six time series sediment-trap moorings positioned along the continental slope off south-western Crete. We discuss here the seasonal pattern of coccolithophore fluxes based on the record from intact coccospheres only. Coccolith data from the present data set, combined with the mechanisms of the modern depositional setting in the south Cretan margin, will be discussed elsewhere. Previous records from different oceanographic settings have shown that coccosphere fluxes are generally 3 to 5 orders of magnitude lower than those of coccoliths. As a consequence, species-specific fluxes of coccosphere species are only rarely discussed ( [De Bernardi et al., 2005] and [Triantaphyllou et al., 2004]). Rather, fluxes are usually described for individual coccoliths ( [Sprengel et al., 2002], [Sprengel et al., 2000] and [Ziveri et al., 2000b]) or refer to the pattern of major coccosphere species only ( [Broerse et al., 2000b] and [Ziveri et al., 2000a]).

In our study, the exceptionally high flux of coccospheres and the large amount of material available for coccosphere counting, enabled us to obtain reliable information on coccosphere fluxes from a large diversity of species for a one-year-cycle. In fact, intact coccospheres are only found in the proximity of the area of production, whereas coccoliths can be re-suspended. Therefore our approach facilitates the capturing of the "real" signal of export production from the photic zone.

In this study we present data on the seasonal coccolithophore production and discuss the export mechanisms controlling their export fluxes in this part of the eastern Mediterranean Sea.

\section{Oceanographic setting}

The south eastern Mediterranean is considered to be one of the most oligotrophic regions in the world (Yacobi et al., 1995), where heterotrophic bacterial production is tightly coupled with primary production. South of Crete, the surface Chl-a concentration, as measured from satellite (NASA Seawifs data, available at http://disc.sci.gsfc.nasa.gov/techlab/giovanni), ranges seasonally from 0.075 to $0.175 \mathrm{mg} \mathrm{m}-3$. Previous data from North of Crete, Cretan Sea and the Straits of the Cretan Arc (Gotsis-Skretas et al., 1999) indicated, for the period 1994-1995, chlorophyll levels varying from $0.22-0.49 \mathrm{mg} \mathrm{m}-3$ in the deep chlorophyll maximum ( 75-100 $\mathrm{m} \mathrm{depth}$ ), whereas the surface values ranged from $0.03-0.06 \mathrm{mg} \mathrm{m}-3$. Seasonal fluctuations in phytoplankton densities, chlorophyll standing stock and phytoplankton production are significant in the area, with maxima occurring in spring and winter and minima in summer and autumn. In particular the existence of a cyclonic/upwelling circulation structure in the Antikithira Strait, as opposed to a more variable hydrodynamic regime in the Kassos Strait, results in higher Chl-a concentrations and shallower chlorophyll-a maxima in the Antikithira Strait during summer in comparison to the corresponding phytoplankton parameters in the Kassos Strait (Kontoyiannis et al., 2005).

Although the entire area of the south Cretan margin can be defined as pelagic $(>200 \mathrm{~m}$ water depth) (Fig. 1), most sediment-trap sites are located rather close to the coastline, so that they can be influenced by local processes occurring on land. Sea surface temperature (SST) and stratification change on a seasonal cycle. SST is highest in August-September and lowest in February-March (Fig. 2a). This is the result of changes in both insolation and physical forcing. In fact, a shallow surface mixed layer persists from May to September (Fig. 2b), allowing SST to rise as a function of solar radiation. Deepening of the seasonal thermocline starts in September-October, as a result of 
increasing wind stress, and produces a thick (up to $100 \mathrm{~m}$ ) surface mixed layer. Deeper mixing occurs from December-January, with the water column becoming completely isothermal until stratification starts back in May.

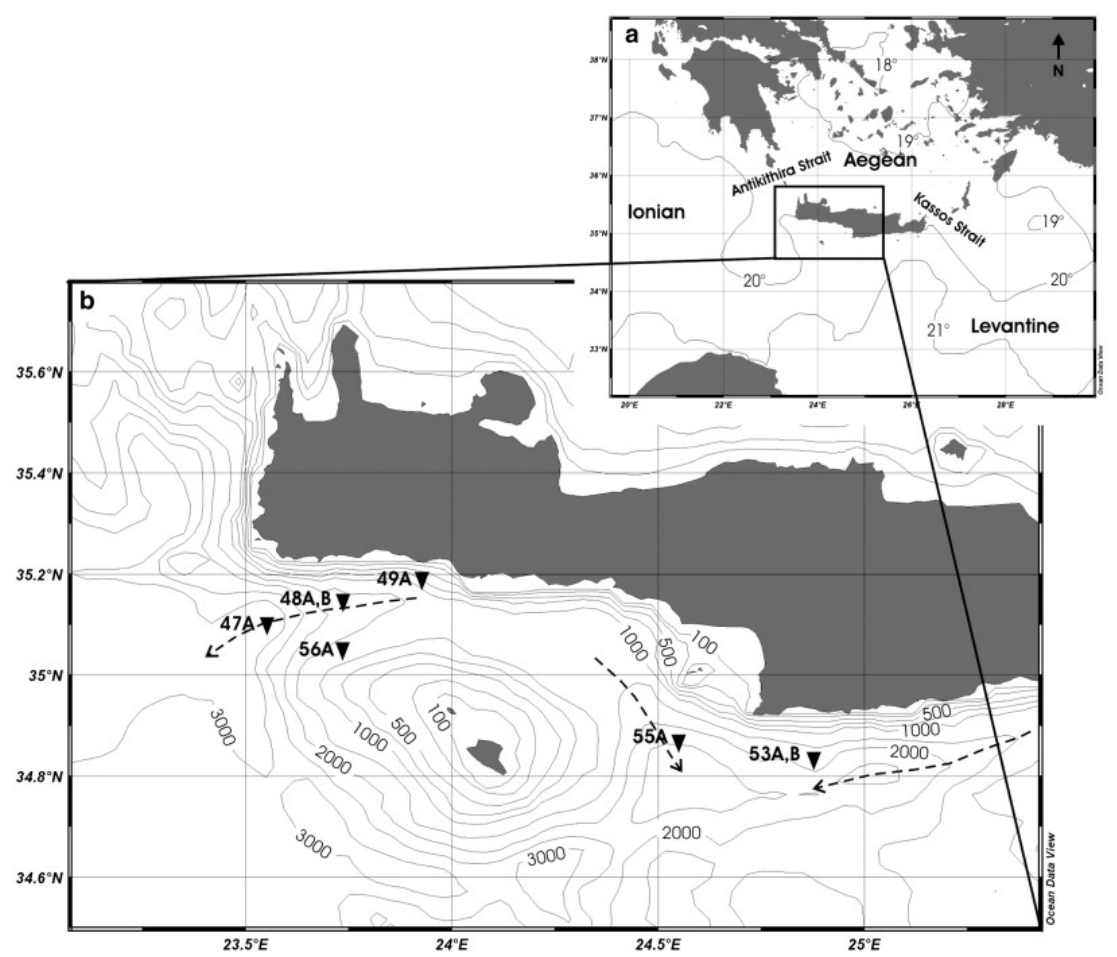

Fig. 1. Map of the investigated area: a) map of the eastern Mediterranean. Isolines are yearly average SST $\left({ }^{\circ} \mathrm{C}\right)$ during the study period, redrawn from OBPG MODIS-Aqua Monthly Global 9$\mathrm{km}$ Products for SST, $4 \mu \mathrm{m}$ night as obtained from http://disc.sci.gsfc.nasa.gov/techlab/giovanni; b) detail of sample locations. Bathymetry is in metres, as obtained from the high resolution Mediterranean bathymetric data in the Ocean Data View packages; dashed arrows indicate the axes of the canyons.

View high quality image (503K) 

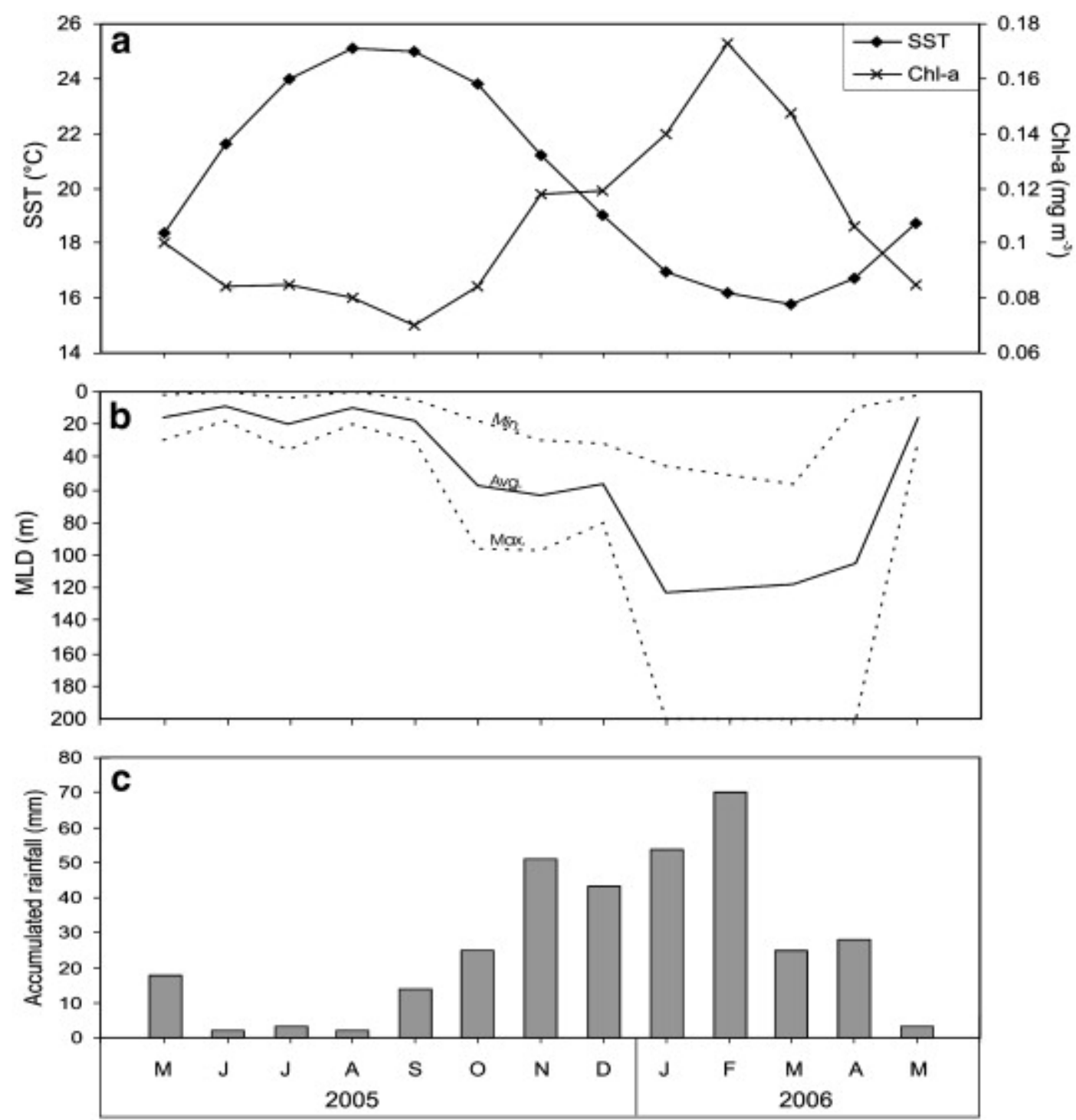

Fig. 2. Oceanographic and satellite-derived data in the study area: a) SST and Chl-a values during the study interval derived from satellite data (for the area 23.5-25.2E/34.8-35.2N): SST are OBPG MODIS-Aqua Monthly Global 9-km Products for SST, $4 \mu \mathrm{m}$ night; Chl-a are OBPG SeaWiFS Monthly Global 9-km Products; b) mixed layer depth: average (Avg.), minimum (Min.) and mximum (Max.) values, calculated from Medatlas II and Woce water column temperature data from the period 1983-2000, available and managed through the Ocean Data View software; c) precipitation over the study area and on the near land (23.5-25.2E/34.9-35.6N) during the sampling interval, expressed as accumulated rainfall $(\mathrm{mm})$, as derived from Monthly TRMM and Other Data Sources Rainfall Estimate. All satellite data are obtained at http://disc.sci.gsfc.nasa.gov/techlab/giovanni/. View high quality image (313K)

The sea surface productivity cycle, as derived from satellite-sensed Chl-a, displays a pattern that is opposite to that of SST and surface water column stratification (Fig. 2a,b). Values are lowest during summer, increase in November-December and reach a maximum from January to March, with a peak in February. Therefore, highest surface productivity coincides with intervals of maximum water column mixing. Through this mechanism nutrients are provided, from deeper in the water column, to the otherwise depleted surface layers.

However, another possible way of nutrient delivery to the surface waters is through external input. Atmospheric dust, mainly of North-African origin, is known to be a major source of micro- and 
macronutrients to the pelagic environment of the eastern Mediterranean. In fact Guerzoni et al. (1999) and Herut et al. (1999) estimated a total input of 0.24 and $0.32 \mathrm{~g} \mathrm{~m}-2$ year- 1 of dustderived inorganic nitrogen and 0.02 and $0.04 \mathrm{~g} \mathrm{~m}-2$ year- 1 of inorganic phosphorous in the eastern to south-eastern Mediterranean, respectively. Dust deposition occurs both through atmospheric fallout, or dry deposition, and through precipitation, or wet deposition. However, wet deposition is estimated to represent $65-80 \%$ of total dust deposition (Molinaroli et al., 1993). The seasonal cycle of precipitation is therefore important in regulating the annual input of dust-related nutrients at the sea surface. Moreover, at near-coast locations, such as our sediment-trap sites, precipitation can provide dissolved nutrients from land, through riverine discharge.

In the study region, including the corresponding drainage area on land, maximum precipitation over the studied annual cycle (May 2005-May 2006) occurred from October to April, with peak values in November and February (Fig. 2c). Potential nutrient input from precipitation occurred therefore synchronous with that provided by water column mixing. Separation of the different contributions is undistinguishable through a simple time series approach.

Finally, the south Cretan margin features a number of post-Miocene tectonic troughs where, in the last $5 \mathrm{Ma}$, turbidite units were deposited (Alves et al., 2007). Many of the canyons in this area are very steep, cutting down into the very narrow shelf and descending to $>3500 \mathrm{~m}$ depth over a very short distance (Fig. 1b). The denudation processes occurring on Crete in response to the tectonic uplift of the island support the presence of high sedimentation rates on the south Cretan margin. This has been accompanied by direct inflow of sediment from alluvial-fan systems and incising mountain rivers onto the continental slope bordering Crete (Alves et al., 2007). These canyon systems are still active nowadays, causing sediment re-suspension along their path and resulting in considerable total mass fluxes measured closed to the bottom (Stavrakakis et al., in prep.).

3. Materials and methods

3.1. Sediment-traps

Six moorings were deployed south of Crete from June 1st, 2005 to May 15th, 2006 (Table 1; Fig. 1). All moorings were equipped with one sediment-trap located about $15 \mathrm{~m}$ above the seafloor, ranging from $\sim 1200$ to $\sim 3500 \mathrm{~m}$ depth; two of the moorings were also equipped with an additional trap located at shallower depth (53B, $697 \mathrm{~m}$; 48B, $995 \mathrm{~m})$. Sediment-traps are PPS3/3 Technicap, with 12 receiving cups and a collection area of $0.125 \mathrm{~m} 2$. A $5 \%$ formaldehyde solution, mixed with filtered seawater and buffered with sodium borate, was used as preservative.

Table 1. Sediment-trap location and depth, average flux of total mass, total carbonate, total coccolithophores and selected coccolithophore species at each station, measured during the study interval.

StationLatitude N Longitude E Collection depth (m) Avg. TMF (mg m-2 day -1$)$

Avg. CaCO3 flux (mg m-2 day -1$)$ Avg. total coccolithophore flux (cs $\times 104 \mathrm{~m}-2$ day -1$)$ Avg. E. huxleyi flux $(\mathrm{cs} \times 104 \mathrm{~m}-2$ day -1$) \quad$ Avg. A. robusta flux $(\mathrm{cs} \times 104 \mathrm{~m}-2$

day-1) Avg. G. flabellatus flux $(\mathrm{cs} \times 104 \mathrm{~m}-2$ day- 1) Avg. F. profunda flux $(\mathrm{cs} \times 104$

m- 2 day- 1) Avg. S. pulchra flux (cs $\times 104 \mathrm{~m}-2$ day- 1) Avg. H. carteri flux (cs $\times 104 \mathrm{~m}-$ 2 day -1$) \quad$ Avg. holococcolithophore flux $(\mathrm{cs} \times 104 \mathrm{~m}-2$ day -1$)$

$\begin{array}{lllllllllllll}\text { 53B } & 34^{\circ} 50.123^{\prime} & 24^{\circ} 52.772^{\prime} & 697 & 242.7 & 45.8 & 190.3 & 74.21 & 39.21 & 6.42 & 6.02 & \\ & 14.147 .95 & 23.60 & & & & & & & & & \\ \text { 48B } & 35^{\circ} 08.732^{\prime} & 23^{\circ} 44.322^{\prime} & 995 & 63.7 & 23.2 & 32.7 & 15.92 & 6.53 & 0.95 & 0.78 & 1.78 \\ & \begin{array}{l}1.80 \\ \text { 49A }\end{array} & \begin{array}{l}35^{\circ} 11.02 \\ 4.786^{\prime}\end{array} & 23^{\circ} 55.854^{\prime} & 1231 & 332.2 & 167.1 & 101.2 & 46.30 & 28.92 & 1.79 & 0.82 & 3.69 \\ & 4.725 .88 & & & & & & & & & & \end{array}$




$\begin{array}{llllllllllll}56 \mathrm{~A} & 35^{\circ} 03.129^{\prime} & 23^{\circ} 44.322^{\prime} & 1301 & 56.6 & 20.2 & 55.6 & 22.77 & 14.44 & 2.29 & 1.29 & 3.44 \\ & 2.37 \quad 5.04 & & & & & & & & & & \\ 53 \mathrm{~A} & 34^{\circ} 50.123^{\prime} & 24^{\circ} 52.772^{\prime} & 1678 & 70.0 & 20.6 & 34.7 & 19.72 & 7.04 & 0.59 & 0.57 & 1.12 \\ & 1.281 .83 & & & & & & & & & & \\ 48 \mathrm{~A} & 35^{\circ} 08.732^{\prime} & 23^{\circ} 44.322^{\prime} & 1967 & 76.9 & 26.2 & 35.1 & 17.78 & 9.83 & 0.58 & 0.56 & 0.86 \\ & 1.54 \quad 1.51 & & & & & & & & & & \\ 55 \mathrm{~A} & 34^{\circ} 52.051^{\prime} & 24^{\circ} 33.026^{\prime} & 2695 & 82.9 & 26.5 & 67.5 & 31.66 & 19.92 & 2.36 & 0.50 & 2.27 \\ & 1.55 \quad 5.83 & & & & & & & & & & \\ 47 \mathrm{~A} & 35^{\circ} 06.032^{\prime} & 23^{\circ} 33.136^{\prime} & 3553 & 60.7 & 19.1 & 40.1 & 25.65 & 7.20 & 0.91 & 0.61 & 0.77 \\ & 1.620 .78 & & & & & & & & & & \end{array}$

Full-size table

Individual sampling intervals were the same for all sediment-traps. They were usually of 15-16 days, excluding selected intervals with a different resolution (Table 2). A hiatus from September 23 rd to October 15th is due to sediment-trap recovery and re-mooring. Other missing data at some intervals are due to either sediment-trap malfunctioning (e.g. final period of 53B, 55A) or intervals for which the material was too low and thus not provided for coccolithophore analysis.

Table 2. Time intervals and collection days of the analyzed sediment-trap samples.

Sample code Time interval Collection days

HCMMI-A1 1/6-15/6/05 15

HCMMI-A2 16/6-30/6/05 15

HCMMI-A3 1/7-15/7/05 15

HCMMI-A4 16/7-31/7/05 16

HCMMI-A5 $1 / 8-15 / 8 / 05 \quad 15$

HCMMI-A6 16/8-31/8/05 16

HCMMI-A7 $1 / 9-7 / 9 / 05 \quad 7$

HCMMI-A8 8/9-15/9/05 8

HCMMI-A9 16/9-22/9/05 7

HCMMI-A10 23/9-30/9/05 7

HCMMII-A1 16/10-15/11/05 31

HCMMII-A2 16/11-15/12/05 30

HCMMII-A3 16/12-31/12/05 16

HCMMII-A4 1/1-15/1/06 15

HCMMII-A5 16/1-31/1/06 16

HCMMII-A6 1/2-15/2/06 15

HCMMII-A7 16/2-28/2/06 13

HCMMII-A8 1/3-15/3/06 15

HCMMII-A9 16/3-31/3/06 16

HCMMII-A101/4-15/4/06 15

HCMMII-A1116/4-30/4/06 15

HCMMII-A121/5-15/5/06 15

Upon recovery of the traps, samples were fixed (with a 5\% formaldehyde solution mixed with filtered seawater and buffered with sodium borate, Stavrakakis et al., 2000) and stored in the dark at $2{ }^{\circ} \mathrm{C}$, until further processing. Swimmers were removed by hand picking under a stereoscope and sub-sampling was undertaken using a peristaltic pump (Perimatic Premier, Jencons Ltd.).

Total mass flux was calculated as in Stavrakakis et al. (2000). Particulate organic carbon (POC) was analyzed using a Perkin Elmer CHN 2400 analyzer and carbonate content was calculated as inorganic carbon $\times 8.33$ (Stavrakakis, pers. comm.). 


\subsection{Coccolithophores}

For coccosphere analysis, each sub-sample was first sieved over a $32 \mu \mathrm{m}$ mesh sieve in order to eliminate the larger fraction, then split into equal fractions using a McLane rotary wet splitter (providing a deviation between aliquots $<4 \%$ ). For each sample, a split fraction was filtered onto a millipore cellulose acetate filter $(0.45 \mu \mathrm{m}$ pore size, $47 \mathrm{~mm}$ diameter $)$, oven dried at $40{ }^{\circ} \mathrm{C}$ and stored in plastic petri dishes.

A portion of each filter was mounted on a glass slide and analysed along radial transects from the center to the edge using a polarized light optical Leica DMLSP microscope (LM) at 1250× to determine the fluxes of total coccospheres per species. A total of 33 to 480 coccospheres were enumerated, for each sample, on an area of approximately $20 \mathrm{~mm} 2$. Taxonomic identifications follow Young et al. (2003), Jordan et al. (2004), Malinverno et al. (2008). Fluxes for each species were then calculated by extrapolating the counted specimens to the entire effective filtration area and total original sample, sampling interval and trap aperture area, following the equation of Ziveri et al. (1999):

\section{(1)}

\section{$\mathrm{F}=\mathrm{N} \times \mathrm{Af} \times \mathrm{S} / \mathrm{af} \times \mathrm{Ast} \times \mathrm{T}$}

where $\mathrm{F}=$ flux (specimens-m-2-day- 1$), \mathrm{N}=$ number of counted specimens, $\mathrm{Af}=$ effective filtration area $(\mathrm{mm} 2), \mathrm{S}=$ split factor, af $=$ investigated filtration area $(\mathrm{mm} 2)$, Ast $=$ sediment-trap aperture area $(\mathrm{m} 2), \mathrm{T}=$ sample collecting time (days).

The majority of the studied sediment-traps were located in close proximity to the bottom $(15 \mathrm{~m}$ above the sea floor) and are thus likely affected by particle re-suspension and lateral transport, which is a large component of the flux especially within canyon-dominated settings. As a consequence, single coccoliths recovered in sediment-traps likely represent both the primary record of export production from the photic zone and the secondary one from re-sedimentation. In contrast, intact coccospheres are usually not preserved in bottom sediments (our observations), so that their occurrence in sediment-traps represents an original signal only.

\section{Results}

\subsection{Total and biogenic fluxes}

Total mass flux displays a marked seasonal pattern which is rather similar at all stations (Fig. 3). A distinct maximum is always present from early June to the end of July: this interval can be slightly longer, lasting until the end of August in the eastern station (55A) or the beginning of September at the deepest trap (47A) or may be followed by other intervals with similar values (until the end of September, i.e. at station 56A, in the western zone). A second less intense flux peak is present at all stations from early March to the end of March. Fluxes are generally low during the winter season (December to February) and again after the March peak. An exception is represented by a further flux increase in April-May, which is only recorded at the easternmost station (53A). 

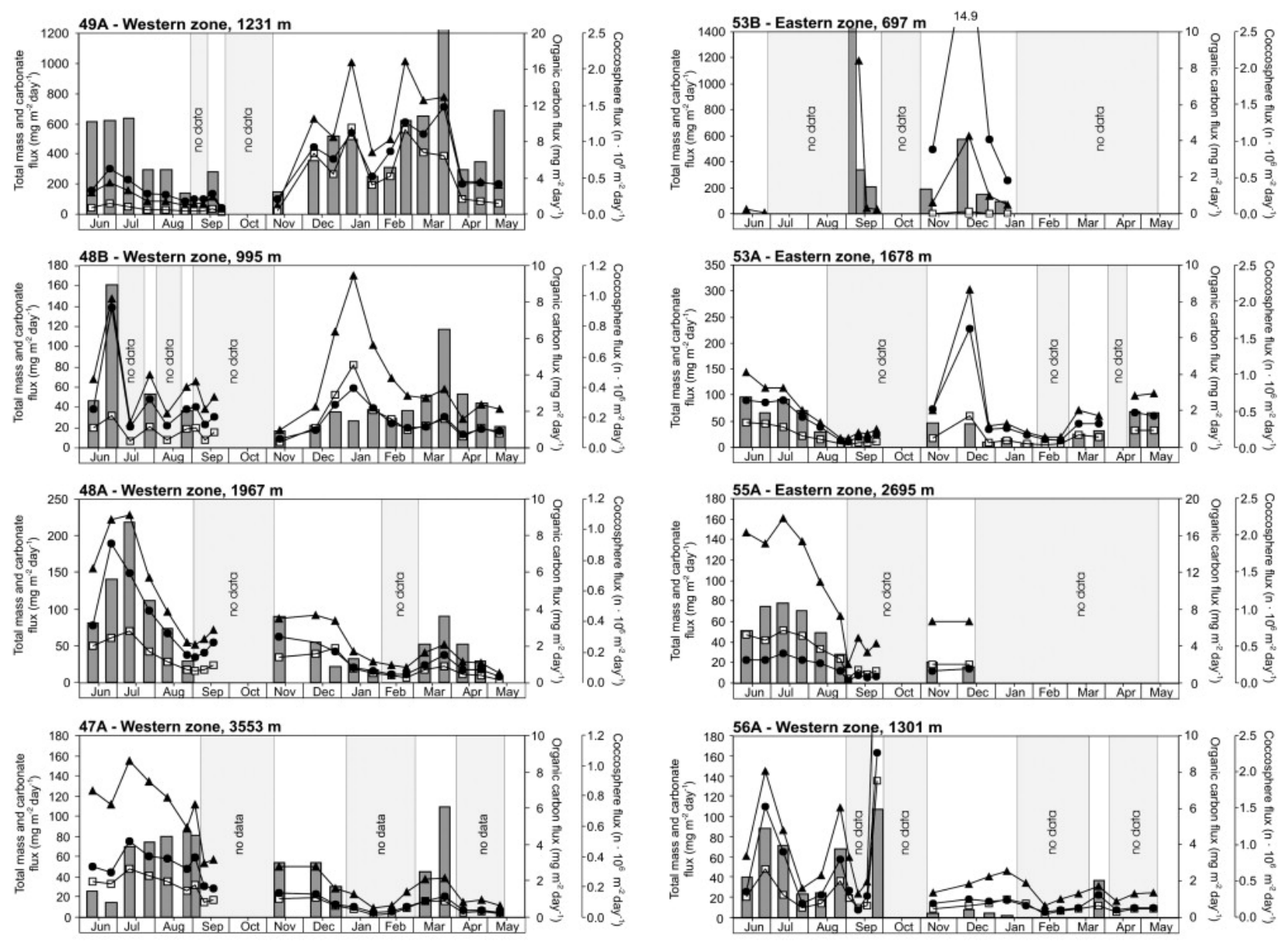

- Total mass flux $\square$ - Total carbonate flux $\quad$ - Total organic carbon flux $\square$ Total coccosphere flux

Fig. 3. Total mass (triangles), carbonate (open squares) and organic carbon (black circles) fluxes combined with total coccosphere fluxes (gray bars) at the different investigated stations. "No data" labels indicate time intervals for which material was not available for the analysis.

View high quality image $(1611 \mathrm{~K})$

Additional features are observed only at selected stations: an intermediate flux increase can be present in middle to late fall (mid October to end of December, i.e. station 48A in the western zone; mid-November to mid-December, i.e. at the easternmost station, 53A-B) or slightly later (midNovember/December-end of January again in the western zone, i.e. station 56A, 48B); a prolonged flux maximum is instead recorded from mid-November to the end of March at the station most close to the coast (49A).

The average total mass flux over the investigated time period, excluding the hiatus interval, ranges from $56 \mathrm{mg} \mathrm{m}-2$ day- 1 (56A) to $332 \mathrm{mg} \mathrm{m}-2$ day- 1 (49A). Such differences are basically related to the different proximity to the coast and the sediment-trap depth.

Biogenic fluxes follow the general trend of the total flux, with some seasonal and lateral differences (Fig. 3).

Organic carbon content usually oscillates between 1.7 and 3\%, with no distinct seasonal pattern at most stations. A distinct seasonal signal is only visible at the western stations (48A-B and 56A), where two distinct peaks of higher organic carbon percent are recorded respectively from early June to the end of July and during March, coinciding with the total mass flux peaks. In contrast, an interval of distinct low organic carbon content $(0.8-1.7 \%)$ is observed at the station most close to 
the coast (49A) from mid-November to the end of March, coinciding with the interval of abnormally high total mass flux.

Carbonate content ranges at all stations from about 30 to $40 \%$ (excluding slightly lower values at the shallowest station, i.e. 53B) of the total mass flux, and only occasionally reaches values of more than $50 \%$ (in the western stations, closer to the coast, i.e. 48A-B, 49A). Significant variations in carbonate content are observed on a seasonal basis. At all the western stations (47A, 48A-B, 49A and less evident at station 56A) carbonate percent is lower during summer-early fall (June to earlyOctober) and increases from fall to spring (mid-October to mid-April), with a slight decrease during the winter months (mid-January to mid-late February); during the winter to spring period, the intervals of higher carbonate content usually coincide with increases in the total mass flux. In contrast, at the easternmost station (53A) carbonate content is high during summer (June to August) and then in spring (March to May), reaching lower values during fall and winter months (October to February). Finally, no significant pattern of variation is observed at station 55A, but this series is interrupted at mid-December.

\subsection{Coccolithophore fluxes and species assemblage composition}

The daily mean coccosphere flux is in the range of $3.2 \times 105-1 \times 106$ coccospheres $\mathrm{m}-2$ day -1 , depending on sampling location and depth. This flux, which can be regarded as the real export production from coccolithophore productivity in the photic zone, parallels to a certain extent that of the total mass flux (Fig. 3). The common seasonal pattern is represented by a double peak in the flux: a major export phase is observed from late June to mid-August $(7 \times 105-1.4 \times 106$ coccospheres $\mathrm{m}-2$ day $-1 ; 1 \times 107$ at station $53 \mathrm{~B}$, but most probably a sampling artifact), then a decrease during fall and minimum values in winter, i.e. 3.5-9 $\times 104$ coccospheres $\mathrm{m}-2$ day -1 ) and a second peak in middle-late March, followed by a slight decrease. Additional features can be observed at selected trap sites: a slight flux increase in mid-September (56A), November (47A, $48 \mathrm{~A}$ ) or December (53B); at the site most close to the coast (49A) much higher fluxes are observed throughout the whole winter and spring season.

The major deviation from the total flux is observed at station 48B, where a large peak in total mass, carbonate and organic carbon fluxes does not correspond to increased coccosphere flux. This peak is indeed anomalous in the seasonal record for the area and is likely caused by re-suspension phenomena (Stavrakakis et al., in preparation).

Preservation of both coccoliths and coccospheres was very good at all samples. The presence of delicate species (holococcolithophores, Discosphaera tubifera), as both intact coccospheres and single coccoliths, indicates that little or no dissolution occurred during either sedimentation through the water column, or sample storage and processing.

Coccolithophore fluxes (coccospheres) at both shallower and deeper traps are dominated by two species, Emiliania huxleyi type A (20-90\%) and Algirosphaera robusta (0-50\%), which on average constitute approximately $75 \%$ of the total assemblage. Other species are represented by Syracosphaera pulchra HET (average 4.2\%), Gladiolithus flabellatus (average 3.1\%), Helicosphaera carteri (average 2.6\%), Florisphaera profunda (average 2\%), S. pulchra HOL oblonga (1.3\%); additional contribution is given by Umbilicosphaera sibogae and $\mathrm{U}$. foliosa (combined abundance $1.1 \%$ ), Coronosphaera mediterranea and $\mathrm{C}$. binodata (combined abundance $1.1 \%$ ) and $\mathrm{H}$. hyalina $(1 \%)$. All other species, although occasionally more abundant at selected intervals, are on average $<$ $1 \%$ and in total they make up to $9.6 \%$ of the assemblage: they are mainly represented by holococcolithophore species (average 3.1\%, excluding S. pulchra HOL oblonga), small Syracosphaera species $(3.3 \%)$ and other minor species. The list of all recovered species is reported in Table 3. 
Table 3. List of coccolithophore species recovered in the studied sediment-trap samples.

Heterococcolithophores

Emiliania huxleyi Hay and Mohler in Hay et al., 1967

Florisphaera profundaOkada and Honjo (1973)

Algirosphaera robusta (Lohmann 1902) Norris 1984

Calciosolenia brasiliensis (Lohmann 1919) Young in Young et al. (2003)

Calcidiscus leptoporus (Murray and Blackman 1898) Loeblich Jr. and Tappan 1978

Coccolithus pelagicus (Wallich 1877) Schiller 1930 subsp. pelagicus

Coronosphaera binodata (Kamptner 1927) Gaarder in Gaarder and Heimdal 1977

Coronosphaera mediterranea (Lohmann 1902) Gaarder in Gaarder and Heimdal 1977

Discosphaera tubifera (Murray and Blackman 1898) Ostenfeld 1900

Gephyrocapsa oceanica Kamptner 1943

Gladiolithus flabellatus (Halldal and Markali 1955) Jordan and Chamberlain 1993

Helicosphaera carteri (Wallich 1877) Kamptner 1954

Helicosphaera hyalina Gaarder 1970

Helicosphaera pavimentumOkada and McIntyre (1977)

Helicosphaera wallichii (Lohmann 1902) Okada and McIntyre (1977)

Ceratolithus cristatus Kamptner HET nischidaeKleijne (1993)(Neosphaera coccolithomorpha var. nishidae)

Oolithotus spp. Reinhardt in Cohen and Reinhardt 1968

Pontosphaera discopora Schiller 1925

Pontosphaera japonica (Takayama 1967) Nishida 1971

Pontosphaera multipora (Kamptner 1948) Roth 1970

Pontosphaera siracusana Lohmann 1902

Rhabdosphaera clavigera Murray and Blackman 1898 (both type clavigera and type stylifera)

Scyphosphaera apsteinii Lohmann 1902

Syracosphaera pulchra Lohmann 1902

Syracosphaera histrica Kamptner 1941

Syracosphaera prolongata Gran 1912 ex Lohmann 1913b

Syracosphaera tumularis Sanchez-Suàrez, 1990

Syracosphaera spp.

Umbellosphaera tenuis (Kamptner 1937) Paasche in Markali and Paasche 1955

Umbilicosphaera foliosa (Kamptner, 1963 ex Kleijne, 1993) Geisen in Sáez et al. (2003)

Umbilicosphaera hulburtiana Gaarder 1970

Umbilicosphaera sibogae (Weber-van Bosse, 1901) Gaarder 1970

Holococcolithophores

Syracosphaera pulchra HOL oblonga ("Calyptrosphaera oblonga")

Syracosphaera pulchra HOL pirus ("Daktylethra pirus")

Helicosphaera carteri HOL solid ("Syracolithus catilliferus")

Helicosphaera carteri HOL perforate ("Syracolithus confuses")

Helladosphaera cornifera (Schiller 1913) Kamptner 1937

Syracosphaera anthos HOL ("Periphyllophora mirabilis")

Undetermined small holococcolithophores

4.3. Seasonal pattern of coccolithophore species flux

The overall seasonal pattern is comparable for all species, with maximum absolute fluxes occurring typically in early spring to early summer (Fig. 4) as shown by the total coccosphere flux. However, considering the percent contribution of the major and minor species/groups to the total flux (Fig. 5 and Fig. 6), a consistent picture is apparent. 

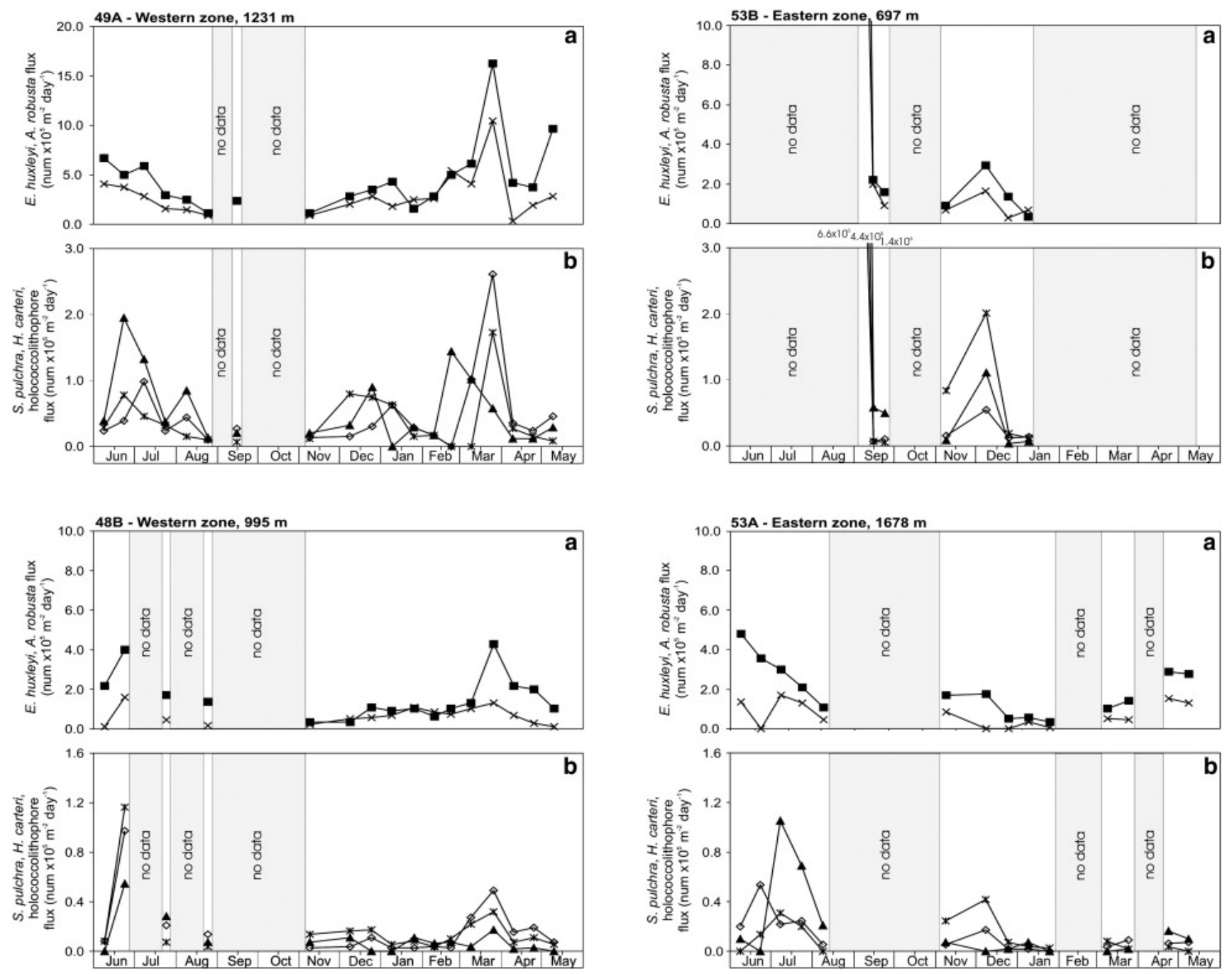

Fig. 4. Fluxes of the most important coccolithophore species (coccospheres) at the different investigated stations. "No data" labels indicate time intervals for which material was not available for the analysis.

View high quality image (1033K) 

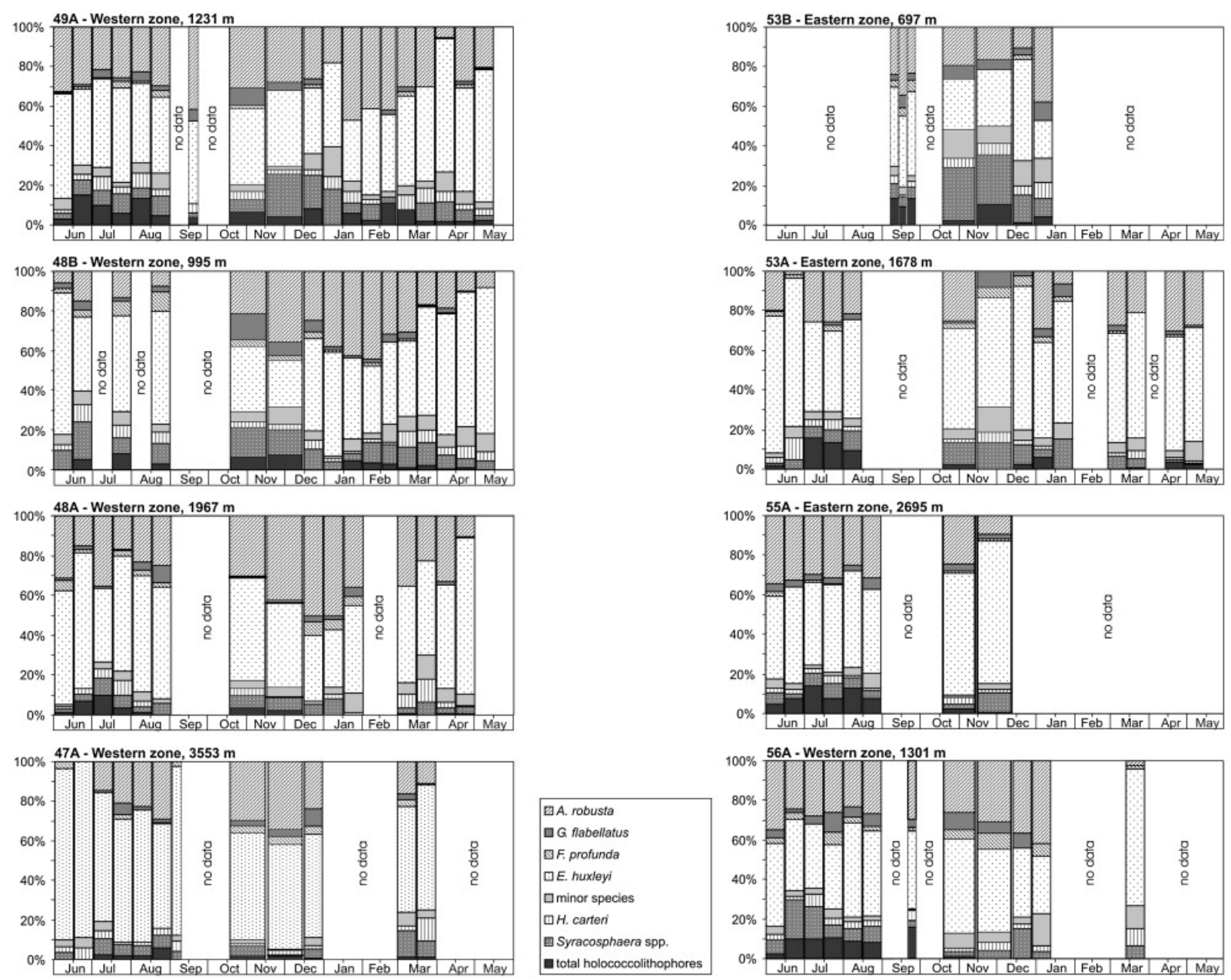

Fig. 5. Relative abundance of major coccolithophore species (coccospheres) at the different investigated stations. "No data" labels indicate time intervals for which material was not available for the analysis.

View high quality image (2967K) 

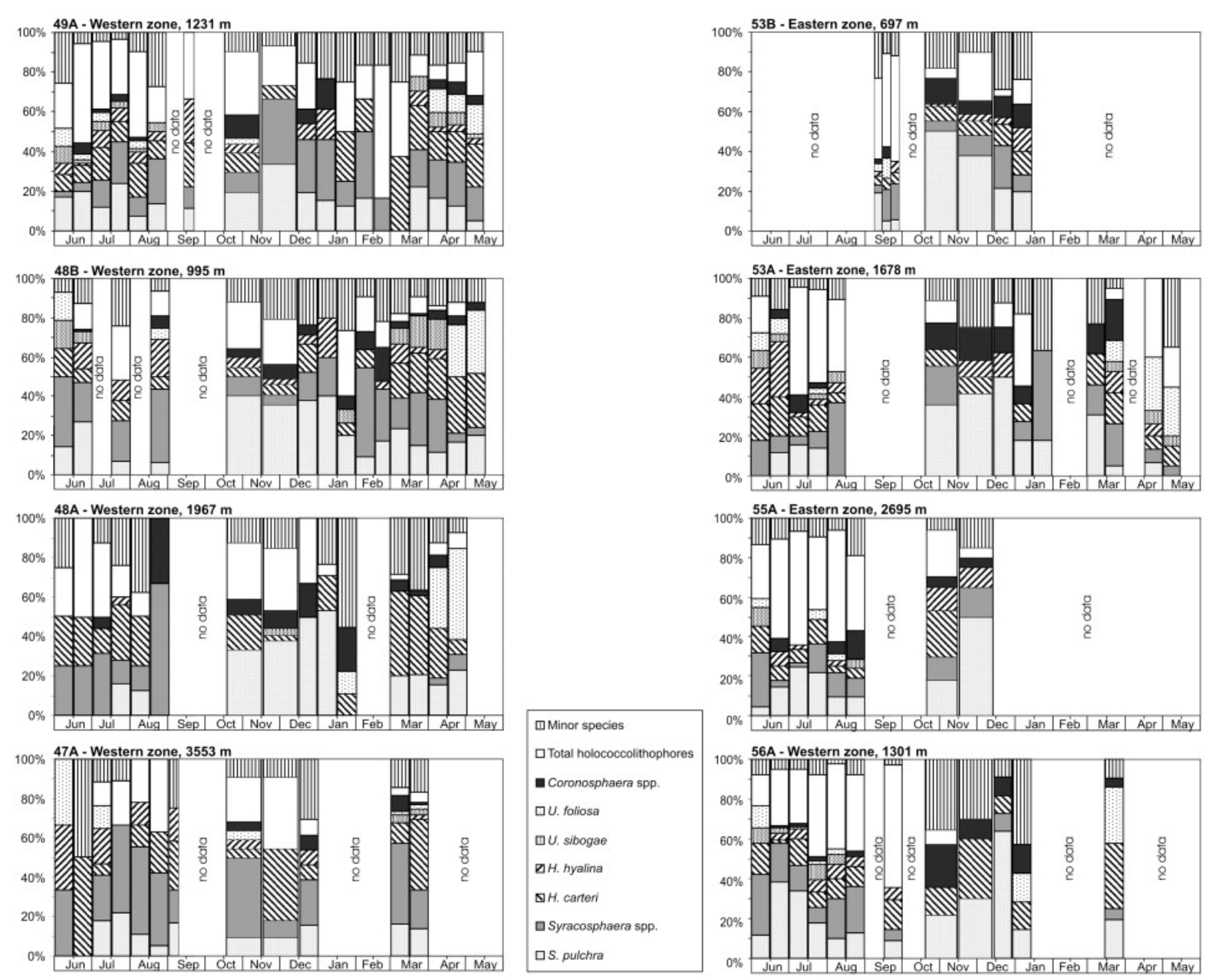

Fig. 6. Relative abundance of the minor coccolithophore species (coccospheres), i.e. all species excluding E. huxleyi and the deep species F. profunda, G. flabellatus and A. robusta. "No data" labels indicate time intervals for which material was not available for the analysis.

View high quality image (2319K)

The fluxes of the two major species recorded in the traps, E. huxleyi and A. robusta, show an overall similar pattern (Fig. 4). Excluding station 53A,B, where a clear pattern is not recognized (also due to the lack of data in some periods), E. huxleyi is more abundant, relative to all other species (Fig. 5), in spring (peak flux in middle-late March) and early summer (June) at almost all stations, during the interval of maximum total coccosphere flux. In contrast, A. robusta shows a relative increase in late summer (late August-September, i.e. 47A, 48A, B, 49A, 55A) and is more abundant during fall and winter (November to early March, 47A, 48A, B, 49A, 56A).

Other species that, like A. robusta, typically thrive in the lower photic zone, F. profunda and G. flabellatus, although much less abundant than A. robusta, display a rather similar trend. Again, excluding station 53A,B, flux maxima occur in summer (June to August) and then in fall to early winter (November to January). The fluxes of the three species are not however completely parallel. In fact F. profunda and G. flabellatus tend to be more important, with respect to A. robusta, during summer and fall: this pattern is well seen at station $48 \mathrm{~A}, \mathrm{~B}$, where the yearly record is more complete, but is less obvious at the other stations. Moreover, F. profunda tends to increase slightly before G. flabellatus, i.e. it is more abundant during late spring-early summer (June), while G. flabellatus is more abundant later in summer and in early fall (July-October).

Helicosphaera spp. display high flux and relative abundance in summer. Fluxes increase in July at all stations, sometimes starting early (late June at 48B, 53A,B) and lasting until August (47A, 
48A,B, 49) or September (56A). Maximum values are reached in middle to late March at all stations (where the record is present). Additionally, there is a slight increase at some stations during restricted intervals in winter (December, 53A,B, 56A or January, 48A,B, 49). Helicosphaera species are mainly represented by $\mathrm{H}$. carteri and $\mathrm{H}$. hyalina, while $\mathrm{H}$. wallichii and $\mathrm{H}$. pavimentum represent a very small contribution. Although $\mathrm{H}$. carteri is on average more abundant than $\mathrm{H}$. hyalina, the latter may dominate at selected intervals during the summer months $(47 \mathrm{~A}, 48 \mathrm{~B}, 53 \mathrm{~A})$. In contrast, H. carteri is the dominant or even exclusive Helicosphaera species during the latewinter to spring high flux period.

S. pulchra (Fig. 4) increases in flux and relative abundance in July and shows a second, usually stronger, peak at all stations in November-December, sometimes extended to early January (49A, 56A) and a third weaker peak in late March, along with the other species. This pattern is rather well observed at all stations.

Total holococcolithophores are more abundant during summer, from June to August, with a peak in July: this pattern is evident at all stations (less obvious at station $47 \mathrm{~A}$ ). An extended maximum is also observed in September (56A) and at some stations also in December (49A, 53B). Overall, there is an almost continuous record for holococcolithophores at station 49A, while they are scarcely represented at station $47 \mathrm{~A}$.

Umbilicosphaera species are represented by U. sibogae and U. foliosa; the third species of this genus, U. hulburtiana, makes a negligible contribution to the coccosphere flux. Both species have a higher relative abundance during spring and summer months, and are nearly absent during fall and winter. At stations $48 \mathrm{~B}$ and 49 , the spring peak of $U$. sibogae precedes by $1-2$ sampling intervals (i.e. 15-30 days) that of U. foliosa; however, at all other stations, the increase of the two species is observed simultaneously and usually corresponds to the interval of high total coccolithophore export flux. On average, U. foliosa has higher relative abundance (avg. 0.7\%) than U. sibogae (avg. $0.4 \%)$.

Rhabdosphaera clavigera and Umbellosphaera tenuis display a very low flux, which is in the same range or even lower than that from other surface-living species that usually represent a very minor fraction, i.e. Coronosphaera spp. and D. tubifera.

R. clavigera displays usually higher flux and relative abundance in summer (July-August, 47A, 48B) and has sporadic peaks during winter-early spring (November, 55A, 48B; January, 48A,B; March, 47A, 49A, 53A), which are usually paralleled by increased relative abundance.

U. tenuis displays generally lower values, with sporadic increase in late summer (July-August, 49A, 53A, 55A), fall (November-December, 47A, 48A,B, 49A, 53A) and/or March (48A, 49A). Its relative abundance is very low (avg. $0.4 \%$ ), but can reach higher values (up to $8 \%$ ) at selected intervals, mostly during summer $(55 \mathrm{~A}, 49 \mathrm{~A})$ to fall $(53 \mathrm{~A}, \mathrm{~B})$. At station $48 \mathrm{~A}, \mathrm{~B}$, an increase is instead recorded during winter-spring.

Coronosphaera species (C. mediterranea + C. binodata) are usually abundant in July at most stations, but can also increase sporadically during fall to spring time (mainly November and late March) at some stations. Among the minor species, they have higher relative abundance during fall and winter.

D. tubifera is present discontinuously throughout the study period; it shows increases during early summer, mid winter and early spring. However, there is no consistent pattern in the seasonal variation of its relative abundance, possibly due to the scarcity of coccosphere data. 


\section{Discussion}

\subsection{Coccolithophore response to seasonally varying ecological factors}

The taxonomic composition of the coccolithophore assemblages was similar at all mooring sites, with some variability mostly related to the proximity to the coast and sampling depth (see 5.4). Based on the seasonal flux pattern of the individual coccosphere species, the assemblage and the species diversity, we were able to clearly define three main productivity periods within the analysed annual cycle:

a) early spring-early summer (March to June): this interval is characterized by high overall total coccosphere flux (Fig. 3). It occurs $\sim 1$ month after the sea surface production peak recorded through remote sensing (Fig. 2a). The assemblage composition of this period is characterized by increased abundance of the cosmopolitan E. huxleyi, which is expected to rapidly respond to the increased nutrient supply to the photic zone, following deep water column mixing. Among the subordinate species, H. carteri s.s., Umbilicosphaera spp. and S. pulchra also increase significantly at this time. Although there is a high number of species, Shannon diversity index (Appendix table) is generally low in this interval, due to the strong dominance of E. huxleyi.

b)

summer-early fall (June to November): this interval is characterized by high but gradually decreasing total coccosphere flux. It starts $\sim 1$ month after the interval of late-spring (May) water column re-stratification (Fig. 2b), followed by the persistence of a shallow surface mixed layer. The remarkable increase in relative abundance of A. robusta, F. profunda, G. flabellatus during this interval indicates that favourable conditions were occurring in the deep photic zone. Besides, high abundance of holococcolithophores (until August), S. pulchra and Coronosphaera spp. and an increase of R. clavigera, U. tenuis and D. tubifera, usually considered as typical from low-nutrient high-temperature areas ( [Nishida, 1979] and [Okada and McIntyre, 1977]) and periods ( [Haidar and Thierstein, 2001], [Okada and McIntyre, 1979] and [Triantaphyllou et al., 2004]), document a well developed surface community, thriving in a stratified upper water column, likely resulting in gradual nutrient depletion in the photic zone. Overall, this interval displays the highest species diversity, likely due to the high SST and stratification, which determine a suitable environment throughout both the upper and the lower photic zone.

c) late fall-winter (November to February): this period is characterized by low overall export fluxes but high species diversity. It corresponds to the time of low SST and surface mixed layer deepening (starting in October), but without complete water column mixing. It shows high relative abundance of A. robusta (but not of the other deep species) and increasing S. pulchra and Syracosphaera spp. 5.2. Ecological implications from selected species

The well established coccolithophore seasonal trends off south-western Crete made possible the definition of species-specific ecological preferences and the investigation of some peculiar aspects of their distribution at our study area.

The most striking feature in the coccolithophore species fluxes analysed in this area is the extremely high concentration of A. robusta, which is on average the second most abundant species in our record. It is present throughout the whole seasonal cycle and becomes even dominant over E. huxleyi at selected intervals. Finding such a high abundance of A. robusta is unprecedented for the world oceans and the eastern Mediterranean (see Table 4).

Table 4. Summary of the known ecological preferences of selected coccolithophore species. 
A. robusta Lives in the deep photic zone of tropical to transitional settings ([Okada and Honjo, 1973], [Okada and McIntyre, 1979], [Reid, 1980], [Knappertsbusch, 1993] and [Takahashi and Okada, 2000])

Found also at shallower depths ([Jordan and Winter, 2000], [Malinverno et al., 2003b] and [Dimiza et al., 2008])

Associated with periods of water column stratification $\quad$ [Broerse et al., 2000a] and [Broerse et al., 2000b]

Responds to limited increase in nutrient concentration Broerse et al. (2000a)

More abundant at non-coastal than coastal sites Sprengel et al. (2002)

Usually a minor component of the total coccolith flux ( [Ziveri et al., 2000b] and [Malinverno et al., in preparation])

Can be seasonally important in oligotrophic settings Triantaphyllou et al. (2004)

Florisphaera profunda and Gladiolithus flabellatus Lives in the deep photic zone of tropical to temperate oceans ( [Okada and Honjo, 1973], [Okada and McIntyre, 1977] and [Winter et al., 1994])

Found at 50 to $200 \mathrm{~m}$ depth in the eastern Mediterranean ( [Knappertsbusch, 1993] and [Malinverno et al., 2003b])

Associated with periods of water column stratification ( [Okada and McIntyre, 1979], [Broerse et al., 2000b], [Haidar et al., 2000], [Sprengel et al., 2000], [Ziveri et al., 2000a], [Cortés et al., 2001] and [Haidar and Thierstein, 2001])

Associated with water transparency ( [Tanaka, 1991] and [Ahagon et al., 1993])

Associated with light availability Haidar and Thierstein (2001)

More abundant in stable oligotrophic open ocean than coastal settings ( [Kinkel et al., 2000], [Sprengel et al., 2002] and [Andruleit and Rogalla, 2002])

Inversely related to coccolithophore productivity ( [Molfino and McIntyre, 1990], [Okada and Matsuoka, 1996] and [Beaufort et al., 1997])

Inversely related to upwelling ( [Jordan et al., 1996] and [Rosteck et al., 1997])

Abundant in highly stratified waters, with elevated nutrients in the subsurface and low light levels

Stoll et al. (2007)

F. profunda dominant over G. flabellatus in most settings, excluding very low latitudes ( [Okada and Honjo, 1973] and [Broerse, 2000])

F. profunda dominant over G. flabellatus in the E. Mediterranean ( [Knappertsbusch, 1993], [Ziveri et al., 2000b], [Malinverno et al., 2003b], [Malinverno et al., 2004] and [Triantaphyllou et al., 2004])

S. pulchra Lives in a wide temperature range ([Okada and McIntyre, 1979] and [Ziveri et al., 2004])

Most abundant in the oligotrophic central gyres Ziveri et al. (2004)

Responds to mesotrophic conditions ( [Newton et al., 1994], [Knappertsbusch and Brummer, 1995] and [Broerse et al., 2000b])

Responds to increased fresh-water input ([Flores et al., 1997] and [Colmenero-Hidalgo et al., 2004])

H. carteri s.l. Typical of warm water settings ( [McIntyre and Bé, 1967] and [Brand, 1994])

Low abundance in oligotrophic settings ( [Knappertsbusch, 1993], [Malinverno et al., 2003b] and [Ziveri et al., 2004])

High concentration the mesotrophic environments ( [Ziveri et al., 1995a], [Andruleit and Rogalla, 2002], [Findlay and Giraudeau, 2001] and [Ziveri et al., 2004])

Correlated to increase in PP Haidar and Thierstein (2001)

Correlated to post-upwelling phases in eutrophic environments ( [Ziveri et al., 1995a], [Ziveri and Thunell, 2000] and [Broerse et al., 2000a])

Responds to higher fresh-water input ([Flores et al., 1997] and [Colmenero-Hidalgo et al., 2004]) 
H. hyalina abundant in upwelling areas Ziveri et al. (2004)

U. sibogae Lives in warm water settings ( [Okada and McIntyre, 1979] and [Winter, 1985])

Found in the oligotrophic central gyres Ziveri et al. (2004)

Inversely correlated with upwelling ( [Kleijne, 1993], [Ziveri et al., 1995b], [Broerse et al., 2000a] and [De Bernardi et al., 2005])

U. foliosa Prefers mesotrophic to eutrophic environments ( [Okada and McIntyre, 1979], [Ziveri et al., 1995b], [Ziveri and Thunell, 2000] and [Andruleit et al., 2005])

Most abundant during post-upwelling phaseBroerse et al. (2000a)

D. tubifera, U. tenuis More abundant in oligotrophic subtropical regions ( [Okada and McIntyre, 1977], [Nishida, 1979], [Kleijne et al., 1989] and [Young, 1994])

Abundant in the eastern Mediterranean ( [Knappertsbusch, 1993] and [Malinverno et al., 2003a])

Coincide with stratified waters and high SST ( [Broerse et al., 2000a] and [Triantaphyllou et al., 2004])

R. clavigera Lives in oligotrophic surface waters Haidar and Thierstein (2001)

Prefers mesotrophic conditions ( [Young, 1994], [Triantaphyllou et al., 2002] and [Dimiza et

al., 2008])

The seasonal cycle delineated by this species' flux indicates its behaviour is similar to that of the other deep species, showing an increase in abundance from late summer to winter, during periods of constant water column stratification. However, our data suggest that in respect to F. profunda and G. flabellatus, the relative abundance of A. robusta increases most significantly during winter, i.e. when the surface mixed layer is deeper (December-January) and nutrients are likely more easily diffused to the lower photic zone from deeper water layers. This species is then overtaken by E. huxleyi when complete water column mixing occurs (February-March).

Higher nutrient availability featuring the deep photic zone of our study area with respect to other settings could favour A. robusta rather than the other two deep-living species. This is otherwise related to the proximity to the coastline, which provides nutrients through the riverine input: the winter increase in A. robusta coincides in fact with the period of maximum rainfall. Our data are therefore in contrast with the observations of Sprengel et al. (2002) at Gran Canaria who supported a preference of $\mathrm{A}$. robusta for open pelagic rather than coast-influenced settings, and add to the view that its flux is just a minor component in the coccolithophore assemblage of the pelagic eastern Mediterranean ( [Ziveri et al., 2000a], [Ziveri et al., 2000b] and [Malinverno et al., in preparation]).

A peculiar aspect of our dataset regards the relatively low abundance of F. profunda coccospheres: fluxes are, on average, lower than those of G. flabellatus, which is in contrast with the subtropical setting of the area (see Table 4). However, examination of the present material showed that indeed F. profunda coccoliths contribute significantly to the total coccolith flux (average $15 \%$, our unpublished data), thus suggesting that coccospheres of F. profunda are highly susceptible to disruption. In fact, most of the literature data summarized in Table 4 refer to loose coccoliths: F. profunda is actually never reported as dominant within the coccospheres, but rather in the coccolith flux (e.g. Broerse et al., 2000b).

Moreover, we can identify a species' shift within the deep photic zone community: coccospheres of F. profunda display a higher relative abundance in early summer (June), while those of G.

flabellatus increase during mid-summer and fall (July-October). Given that the two species usually occupy the same ecological niche in tropical to temperate settings, this shift could be explained by the preference of G. flabellatus for higher temperature and/or a more stable stratification of the water column, as it has been already evidenced by its higher abundance in very low latitude settings (Broerse, 2000). 
Some new ecological information can be obtained from this work for the different species of Helicosphaera s.l. In fact knowledge about their specific ecology is limited, due to the fact that they were most often combined in ecological studies, as varieties of the same species. After their recent separation at species level (Sáez et al., 2003), Ziveri and others (2004) report elevated abundance of $\mathrm{H}$. hyalina in the upwelling area off NW Africa. However, no specific information is given about $\mathrm{H}$. carteri s.s. in relation to the other Helicosphaera species.

In our samples, we observed a preference of H. carteri s.s. for the spring high flux interval. This species is therefore responsive to the seasonal pattern of nutrient availability in the photic zone, due to either water column mixing or increase in fresh-water input, related to higher precipitation. In contrast, $\mathrm{H}$. hyalina was most abundant in late spring-summer, thus corresponding to an interval of rather high SST and intermediate nutrient conditions. Instead, H. wallichii was present only sporadically, so that no inference can be drawn on its ecological preferences.

Concerning the distribution of S. pulchra in our samples, this species is abundant during summer (July), within well stratified surface waters. However, it is also abundant in October and shows peak values in November, in correspondence with a deepening mixed layer and an increase in rainfall. Finally, it is an important component of the coccolithophore flux during the March export production peak. Therefore our data confirm that S. pulchra thrives well in oligotrophic stratified waters, but also responds efficiently to increased nutrient availability and/or lowered salinity associated with increased rainfall, supporting recent inferences from surface sediments (Ziveri et al., 2004).

The flux patterns of $U$. sibogae and $U$. foliosa in the study area exhibit some differences from literature data (Table 4). In fact the two species reveal here the same seasonal trend, with a simultaneous increase during the interval of high total coccosphere flux (March), presence but decreasing abundance until mid-summer (August) and absence from the winter samples. Therefore they both seem to respond positively to the increased nutrient availability that follows the seasonal water column mixing, revealing a tendency for mesotrophic to eutrophic conditions. The absence of both U. sibogae and U. foliosa during winter, when the upper water column is mixed and SST is low, could imply that their distribution is also limited by temperature in our study area.

The extremely low flux of U. tenuis, D. tubifera, R. clavigera in the present samples throughout the whole study period (average relative abundance of $0.4,0.5$ and $0.8 \%$, respectively) is probably inferring that this area is not as oligotrophic as the rest of the eastern Mediterranean. This can be due to the influence of the coastal zone, providing nutrients through river discharge.

\subsection{Overall seasonality and depth of production}

The investigated area, as well as most areas of the eastern Mediterranean Sea, is characterized by a seasonal surface production typical of subtropical-temperate zones, as detected from satellitesensed chlorophyll concentration. Production maxima occur in late winter-spring, during the water column mixing phase, which also coincides with the interval of increased rainfall. Coccolithophore assemblages, as inferred by their fluxes, enable tracking the seasonal shift in the main depth of production within the upper water column (Fig. 7). 


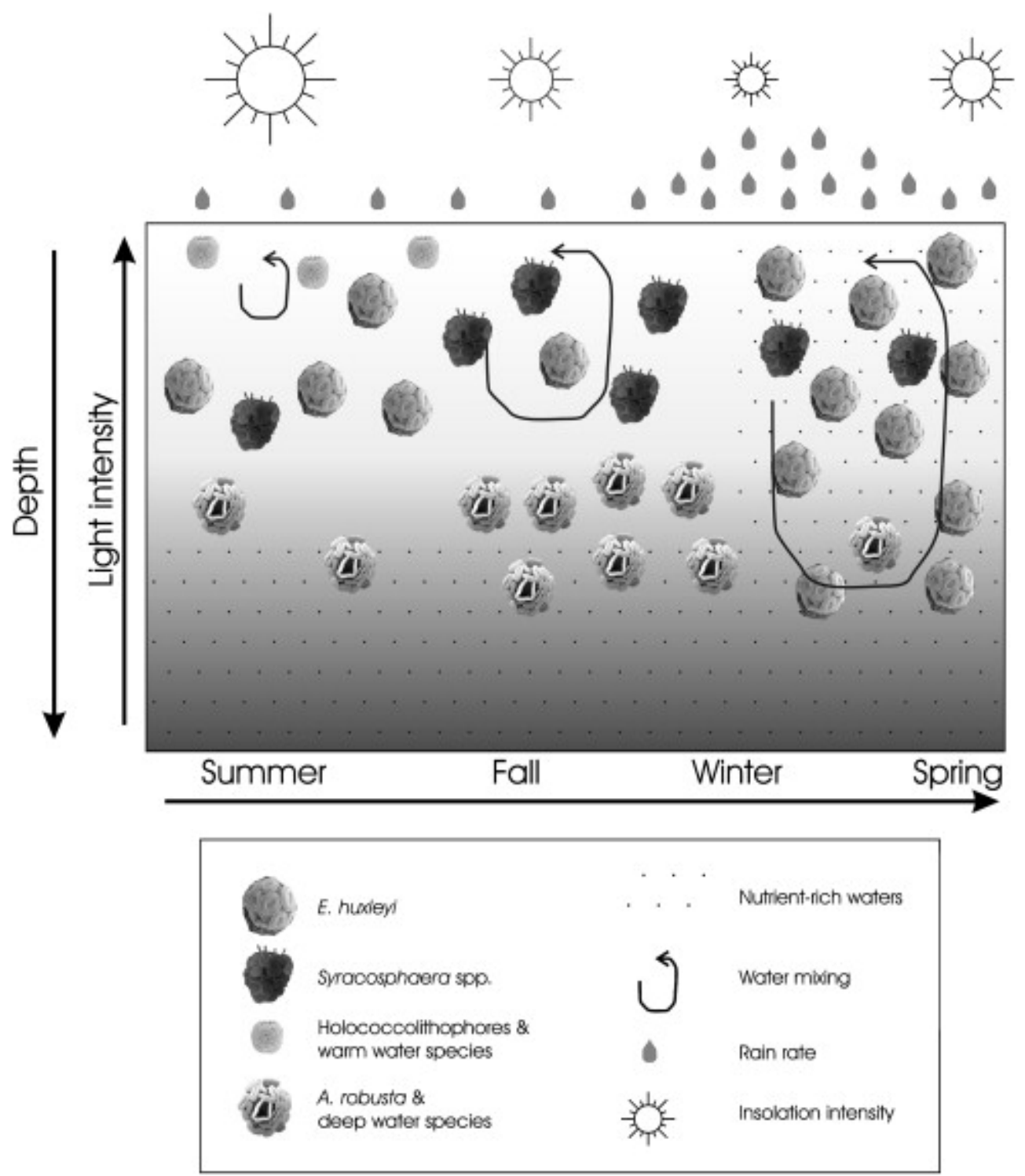

Fig. 7. Schematic evolution of the seasonal forcing and the oceanographic conditions affecting the coccolithophore assemblages and their related fluxes. The most significant coccolithophore species are grouped according to their ecological preferences.

View high quality image (520K)

In our dataset at the south-western margin of Crete, the coccolithophore fluxes document the maintenance of an extended deep chlorophyll maximum (DCM) year round, as testified by the permanent occurrence of deep-living species (A. robusta, F. profunda, G. flabellatus). In particular, with respect to the surface productivity, the formation of a DCM is most enhanced from late summer to winter, when the sum of deep species recovered in sediment-traps represents up to 50 $60 \%$ of the total coccolithophore community. Similar results have been recorded at the Cretan Sea, north of Crete Island, where the relative abundance of F. profunda was more intense during the low coccolithophore productivity interval (Triantaphyllou et al., 2004), pointing to a deeper nutricline according to the model of Molfino and McIntyre (1990). During this interval in our study area, there is a maximum in coccolithophore export production developing at depth, although satellite-detected surface chlorophyll concentration is low. In contrast, during the water column mixing event occurring in early spring, coccolithophore productivity is mainly undertaken by opportunistic species (E. huxleyi, H. carteri, Umbilicosphaera spp.) which are not restricted to, but most abundant in the surface layers. In fact, during this interval the coccolithophore export peak coincides with the remote-sensed increase in surface chlorophyll concentration. 
The results of coccolithophore export production from this study underscore the seasonal control of primary production at the DCM, which is a common feature of the eastern Mediterranean (e.g. Georgopoulos et al., 2000), as well as of other oligotrophic environments of the world's oceans (e.g. Fenchel, 1988). The depth of the DCM is controlled by the thermo-nutricline structure and thus fluctuates seasonally in depth (e.g. [Psarra et al., 2000] and [Tselepides et al., 2000]). Primary production at the DCM is estimated to be at times even more important than surface production in the eastern Mediterranean (Gotsis-Skretas et al., 1999), but is often overlooked, due to the lack of in situ measurements.

\subsection{Spatial variability and effects on preservation state of the observed coccosphere fluxes} Site-to-site differences are detected in the record of coccolithophore species fluxes, aside from the correspondence of the observed seasonal pattern. These differences include species diversity and the abundance of holococcolithophore species and are probably due to both the different location of the sediment-trap moorings (i.e. proximity to the coast) and a different collection depth (i.e. dissolution or coccosphere disaggregation). However these two factors produce similar effects, so that it is difficult to discriminate between them.

For example, holococcolithophores, which are an important component of the eastern Mediterranean coccolithophore flora (Kleijne, 1991), are often more abundant in neritic than pelagic environments ( [Triantaphyllou et al., 2002] and [Dimiza et al., 2008]). Moreover, they are more susceptible to dissolution than heterococcolithophores, so that they tend to be more abundant in shallower sediment-traps (Ziveri et al., 2000a), decreasing with collection depth. In addition, coccospheres formed by holococcolithophores have loosely connected coccoliths and are therefore prone to disruption during settling.

In the present dataset, holococcolithophores are more abundant, on a yearly average, at station 49A and 53B. A decrease in abundance with increasing sediment-trap depth can be detected, although not significant, in the upper part of the water column: slightly decreasing values ( $3 \%$ to $2.7 \%)$ are observed from $\sim 1000$ to $\sim 2000 \mathrm{~m}$ depth at station 48 ; high values $(5.5 \%)$ are recorded at $1300 \mathrm{~m}$ (station 56A) and still at $2700 \mathrm{~m}(55 \mathrm{~A}$, although the record is mainly from the summer season, when holococcolithophores are more abundant, so that it can overestimate the average annual contribution). At greater depth, however, holococcolithophores represent a very minor fraction of the total coccosphere flux. They are in fact only $1.6 \%$ of the assemblage at $>3500 \mathrm{~m}$ at station $47 \mathrm{~A}$, which is also the site that is located farthest from the coast.

Station 49A is the only site which is rather close to the coast. Here, a continuous holococcolithophore community is recorded throughout the year in the flux, in contrast with the record from all other stations, where holococcolithophores are only present during the summer season. However, the total abundance of holococcolithophores and their species composition at station 49A are not significantly different from those at the other sites, so that we can infer the influence of coastal proximity is not so strong here. Moreover, the comparable relative abundance of A. robusta at all mooring sites could support this inference, even though the preference of this species for coast-influenced or open oceanic environments is still not verified.

The effects of preservation state on the record of the studied species composition can be due to both surface water coccolith calcite dissolution (Milliman et al., 1999) and coccosphere disruption. The presence of delicate and dissolution-prone species in the record from all stations, including the deepest site (47A), indicates that dissolution is not significant in our dataset. Concerning coccosphere disruption, the holococcolithophore abundance data discussed above indicate that it might only be important at elevated (i.e. $>2700 \mathrm{~m}$ ) depth. Moreover, we can better estimate the 
effect of coccosphere disruption through the observation of the varying dominance of E. huxleyi at the different sediment-trap sites and depths. In fact E. huxleyi possesses a well interlocked coccosphere and is the only extant species which is occasionally preserved also in the Holocene eastern Mediterranean sediments. In the sediment-traps under study, the average relative abundance of E. huxleyi ranges from $35-48 \%$ in shallow $(<1300 \mathrm{~m})$ traps to $>50 \%$ at intermediate $(1600$ $2600 \mathrm{~m})$ depth to $\sim 65 \%$ at the deepest site $(>3500 \mathrm{~m})$. Given the rather close proximity of the studied stations and their similar assemblage composition, the relative increase of E. huxleyi with depth likely reflects increasing coccosphere disruption of the other species during sinking.

Our observations can definitely prove that the depth of sediment-trap mooring has a strong control on the preservation of the original record from coccolithophore production, even when dissolution does not occur. This should always be considered when comparing coccolithophore data from different locations.

\subsection{Coccolithophore export production at the south-western Cretan margin compared to different oceanographic settings}

The calculated average coccosphere flux ranges from 0.3 to $1.3 \times 106$ coccospheres $\mathrm{m}-2$ day -1 at the different locations and depths investigated. Collection depth ranges from 697 to $3550 \mathrm{~m}$ and thus affects the entity and composition of the coccosphere flux, as discussed in the previous section. Comparison with previous data from different oceanographic settings indicate that the values we find at our sediment-traps are slightly lower than those found for the subtropical North Atlantic (4.9 $\times 106$ coccospheres $\mathrm{m}-2$ day -1 at $1000 \mathrm{~m}$, i.e. Broerse et al., 2000b), rather similar to those of the temperate North Atlantic (e.g. $8.45 \times 105$ coccospheres $\mathrm{m}-2$ day- 1 at $1000 \mathrm{~m}$, i.e. [Broerse et al., 2000b] and [Ziveri et al., 2000a]). Seasonal coccosphere fluxes minima $(0.7-10 \times 106$ coccospheres $\mathrm{m}^{-} 2$ day -1$)$ and maxima $(0.3-3 \times 105$ coccospheres $\mathrm{m}-2$ day -1$)$ are close to that of the eutrophic central tropical Pacific (Broerse, 2000), but smaller than those of upwelling-influenced subtropical areas (e.g. Arabian Sea, [Andruleit et al., 2000] and [Broerse et al., 2000a]; Santa Barbara Basin, De Bernardi et al., 2005; Gulf of California, Ziveri and Thunell, 2000; San Pedro Basin, Ziveri et al., 1995a).

For the Mediterranean Sea, there are only a few previous data on coccosphere fluxes. In the pelagic Ionian Sea, average measured fluxes are $4.4 \times 104$ and $1.7 \times 104$ coccospheres $\mathrm{m}-2$ day -1 at 500 and $2800 \mathrm{~m}$ respectively (Malinverno et al., in preparation) and similar values were measured by Ziveri et al. (2000b) at $3000 \mathrm{~m}$. In the Cretan Sea, Triantaphyllou et al. (2004) recorded an average annual flux of $3 \times 105$ and $0.9 \times 105$ coccospheres $\mathrm{m}-2$ day -1 at 500 and $1700 \mathrm{~m}$ depth, respectively.

The present dataset represents therefore an exceptionally high coccosphere flux for an area which is characterised by low overall satellite-detected primary productivity. Given the peculiar species assemblage composition discussed in Section 5.2, we might speculate that our study area is not so oligotrophic, sustaining an extended coccolithophore production. An influence from the coastal zone, providing nutrients from riverine discharge, can be considered.

\section{Conclusions}

In this paper we presented a dataset of coccolithophore export production from eight sediment-trap time series, located in the canyon system area offshore the south-western margin of Crete and covering a one-year cycle. During the whole investigated period, fluxes of coccospheres were significantly high, thus allowing to analyze the seasonal pattern of coccolithophore export production, with the following main conclusions: 
E. huxleyi and A. robusta were the most abundant species during the whole investigated period at all stations. Other species were S. pulchra HET, G. flabellatus, H. carteri, F. profunda, S. pulchra HOL oblonga, while the rest of the species represented $\sim 1 \%$ of the assemblage. The coccosphere flux showed a distinct seasonal cycle, recognizable in the record from all traps, in both total assemblage and species composition. Two coccolithophore export maxima are in fact detected at all locations, in March-April (up to $4.3 \times 105-3.4 \times 106$ coccospheres $\mathrm{m}-2$ day- 1 ) and in late June to mid-August (up to $7 \times 105-1.4 \times 106$ coccospheres $\mathrm{m}-2$ day- -1 ) and broadly correspond to an increase in total mass and carbonate flux.

2.

The period of maximum coccosphere export in March-April is dominated by E. huxleyi, followed by H. carteri s.s., Umbilicosphaera spp. and S. pulchra: this assemblage testifies an increased nutrient availability, which corresponds to the interval of maximum water column mixing and maximum rainfall. The second peak in coccolithophore export, from June to mid-August, is characterized by the simultaneous increase of the deep assemblage and the umbelliform and holococcolithophore group, indicating coccolithophore production occurring throughout the whole photic zone: this interval corresponds to a period of water column stratification and high SST, when nutrients are likely depleted in the surface mixed layer but still available in the lower photic zone through diffusion from the underlying water masses. The interval of lowest coccolithophore export coincides with lowering SST and deepening of the surface mixed layer.

3.

New species-specific ecological information were drawn for some species: among the most significant, A. robusta displayed unprecedented high fluxes, showing an affinity for near-coastal settings; H. carteri showed affinity for eutrophic conditions which occurred as a response to water column mixing and/or increase in fresh-water input.

4.

Slight site-to-site variations in the coccolithophore assemblage record can be explained as a function of the different collection depth: coccosphere disruption progresses during sinking through the water column, resulting in a relative increase, in the deeper traps, of species possessing a more robust coccosphere, such as E. huxleyi.

5.

Overall, the development of the coccolithophore communities and their related export indicate a strong seasonality in planktonic production, which develops in either surface or sub-surface layers. Seasonality appears to be strongly controlled by the co-occurrence of different inter-related factors, such as the annual sea surface temperature cycle, the seasonal alternation of upper water column stratification and wind-driven mixing processes and the external input of nutrients through riverine or precipitation-mediated atmospheric sources.

6.

The coccolithophore fluxes at the south-western margin of Crete document the persistence of an extended DCM year round. In particular, relative to the upper photic zone production, the importance of the production at the DCM depth is most pronounced during the time interval from late summer to mid winter.

Acknowledgments

This work has been possible thanks to the partial support from the European Science Foundation (ESF) under the EUROCORES Programme EuroCLIMATE, through contract No. ERAS-CT-2003980409 of the European Commission, DG Research, FP6 and to the financial support of 04EP59 ENTER Project of the European Union and the General Secretariat for Research and Technology, Greek Ministry of Development. The samples for this study were provided by HERMES project (European Commission FP6). We thank Heather Stoll and an anonymous reviewer for their valuable suggestions for the improvement of the manuscript.

References

Ahagon et al., 1993 


\section{N. Ahagon, Y. Tanaka, H. Ujiié}

Florisphaera profunda, a possible nannoplankton indicator of late Quaternary changes in sea-water turbidity at the northwestern margin of the Pacific

Marine Micropaleontology, 22 (1993), pp. 255-273

Article | PDF (3130 K) | View Record in Scopus | Cited By in Scopus (90)

Alves et al., 2007

T. Alves, V. Lykousis, D. Sakellariou, S. Alexandri, P. Nomikou

Constraining the origin and evolution of confined turbidite systems: southern Cretan margin,

Eastern Mediterranean Sea $\left(34^{\circ} 30-36^{\circ} \mathrm{N}\right)$

Geo-Marine Letters, 27 (2007), pp. 41-61

View Record in Scopus | Full Text via CrossRef $\mid$ Cited By in Scopus (5)

Andruleit and Rogalla, 2002

H. Andruleit, U. Rogalla

Coccolithophores in surface sediments of the Arabian Sea in relation to environmental gradients in surface waters

Marine Geology, 31 (32) (2002), pp. 1-22

Andruleit et al., 2000

H. Andruleit, U. von Rad, A. Bruns, V. Ittekkot

Coccolithophore flux from sediment trap in the northeastern Arabian Sea off Pakistan

Marine Micropaleontology, 38 (2000), pp. 285-308

Article | PDF (3453 K) | View Record in Scopus | Cited By in Scopus (32)

Andruleit et al., 2005

H. Andruleit, U. Rogalla, S. Stäger

Living coccolithophores recorded during the onset of upwelling conditions off Oman in the western Arabian Sea

Journal of Nannoplankton Research, 27 (2005), pp. 1-14

Beaufort et al., 1997

L. Beaufort et al.

Insolation cycles as a major control of equatorial Indian Ocean primary production

Science, 278 (1997), pp. 1451-1454

Brand, 1994

L.E. Brand

Physiological ecology of marine coccolithophores

A. Winter, W.G. Siesser (Eds.), Coccolithophores, Cambridge University Press, Cambridge (1994), pp. 39-49

Broerse, 2000

Broerse, A.T.C., 2000. Coccolithophore export production in selected ocean environments:

seasonality, biogeography, carbonate production. Ph.D. Thesis, Vrije Universiteit, Amsterdam, 185 pp.

Broerse et al., 2000a 
A.T.C. Broerse, G.-J.A. Brummer, J.E. van Hinte

Coccolithophore export production in response to seasonal upwelling off Somalia (northwest Indian Ocean)

Deep-Sea Research II, 47 (2000), pp. 2179-2205

Broerse et al., 2000b

A.T.C. Broerse, P. Ziveri, J.E. van Hinte, S. Honjo

Coccolithophore export production, species composition, and coccolith-CaCO3 fluxes in the NE Atlantic $\left(34^{\circ} \mathrm{N} 21^{\circ} \mathrm{W}\right.$ and $\left.48^{\circ} \mathrm{N} 21^{\circ} \mathrm{W}\right)$

Deep-Sea Research II, 47 (2000), pp. 1877-1905

Colmenero-Hidalgo et al., 2004

E. Colmenero-Hidalgo, J.A. Flores, F.J. Sierro, M.Á. Bárcena, L. Löwemark, J. Schönfeld, J.O.

Grimalt

Ocean surface water response to short-term climate changes reealed by coccolithophores from the Gulf of Cadiz (NE Atlantic) and Alboran Sea (W Mediterranean)

Palaeogeography, Palaeoclimatology, Palaeoecology, 205 (2004), pp. 317-336

Cortés et al., 2001

M.Y. Cortés, J. Bollman, H.R. Thierstein

Coccolithophore ecology at the HOT station Aloha, Hawaii

Deep-Sea Research II, 48 (2001), pp. 1957-1981

De Bernardi et al., 2005

B. De Bernardi, P. Ziveri, E. Erba, R.C. Thunell

Coccolithophore export production during the 1997-1998 El Niño event in Santa Barbara Basin

(California)

Marine Micropaleontology, 55 (2005), pp. 107-125

Dimiza et al., 2008

M. Dimiza, M.V. Triantaphyllou, M.D. Dermitzakis

Seasonality and ecology of living coccolithophores in Eastern Mediterranean coastal environments (Andros Island, Middle Aegean Sea)

Micropaleontology, 54 (2008), pp. 159-175

Findlay and Giraudeau, 2001

C.S. Findlay, J. Giraudeau

Extant calcareous nannoplankton in the Australian sector of the Southern Ocean (austral summers 1994 and 1995)

Marine Micropaleontology, 40 (4) (2001), pp. 417-439

Fenchel, 1988

T.M. Fenchel

Marine plankton food chains 
Annual Review of Ecology and Systematics, 19 (1988), pp. 19-38

Flores et al., 1997

J.A. Flores, F.J. Sierro, G. Francés, A. Vázquez, I. Zamarreňo

The last 100,000 years in the western Mediterranean: sea surface water and frontal dynamics as revealed by coccolithophores

Marine Micropaleontology, 29 (1997), pp. 351-366

Georgopoulos et al., 2000

D. Georgopoulos, G. Chronis, V. Zervakis, V. Lykousis, S. Poulos, A. Iona

Hydrology and circulation in the Southern Cretan Sea during the CINCS experiment (May 1994-

September 1995)

Progress in Oceanography, 46 (2000), pp. 85-112

Gotsis-Skretas et al., 1999

O. Gotsis-Skretas, K. Pagou, M. Moraitou-Apostolopoulou, L. Ignatiades

Seasonal horizontal and vertical variability in primary production and standing stocks of phytoplankton and zooplankton in the Cretan Sea and the Straits of the Cretan Arc (March 1994January 1995)

Progress in Oceanography, 44 (1999), pp. 625-649

Guerzoni et al., 1999

S. Guerzoni et al.

The role of atmospheric deposition in the biogeochemistry of the Mediterranean Sea

Progress in Oceanography, 44 (1999), pp. 147-190

Haidar and Thierstein, 2001

A.T. Haidar, H.R. Thierstein

Coccolithophore dynamics off Bermuda $(\mathrm{N}$

Atlantic). Deep-Sea Research II, 48 (2001), pp. 1925-1956

Haidar et al., 2000

A.T. Haidar, H.R. Thierstein, W.G. Deuser

Calcarous phytoplankton standing stocks, fluxes and accumulation in Holocene sediments off

Bermuda (N. Atlantic)

Deep-Sea Research II, 47 (2000), pp. 1907-19938

Herut et al., 1999

B. Herut, M.D. Krom, G. Pan, R. Mortimer

Atmospheric input of nitrogen and phosphorous to the Southeast Mediterranean: sources, fluxes, and possible impact

Limnology and Oceanography, 44 (7) (1999), pp. 1683-1692 
Jordan and Winter, 2000

R.W. Jordan, A. Winter

Assemblages of coccolithophorids and other living microplankton off the coast of Puerto Rico during January-May 1995

Marine Micropaleontology, 39 (2000), pp. 113-130

Jordan et al., 1996

Jordan, R.W., Zhao, M., Eglinton, G. and Weaver, P.P.E., 1996. Coccoliths and alkenone stratigraphy and paleoceanography at an upwelling site off NW Africa (ODP 658C) during the last 130,000 years. In: A. Moguilevsky and R. Whatley (Editors), Microfossils and Oceanic Environments. University of Wales, Aberystwyth Press, Aberystwyth, pp. 111-130.

Jordan et al., 2004

R.W. Jordan, L. Cros, J.R. Young

A revised classification scheme for living haptophytes

Micropaleontology, 50 (supplement 1) (2004), pp. 55-79 appendices 1-4

Kamptner, 1963

E. Kamptner

Coccolithineen-Skelettreste aus Tiefeeablagerungen des Pazifischen Ozeans

Nathur. Mus. Wien, 66 (1963), pp. 139-204

Kinkel et al., 2000

H. Kinkel, K.-H. Bauman, M. Cepeck

Coccolithophores in the equatorial Atlantic Ocean: response to seasonal and Late Quaternary surface water variability

Marine Micropaleontology, 39 (2000), pp. 87-112

Kleijne, 1991

A. Kleijne

Holococcolithophorids from the Indian Ocean, Red Sea, Mediterranean Sea and North Atlantic

Ocean

Marine Micropaleontology, 17 (1991), pp. 1-76

Kleijne, 1993

Kleijne, A., 1993. Morphology, taxonomy and distribution of extant Coccolithophorids. Ph.D.

Dissertation Thesis, Free University, Amsterdam, 321 pp.

Kleijne et al., 1989

A. Kleijne, D. Kroon, W. Zevenboom

Phytoplankton and foraminiferal frequencies in northern Indian Ocean and Red Sea surface waters

Netherland Journal of Sea Research, 24 (1989), pp. 531-539

Knappertsbusch, 1993

M. Knappertsbusch 
Geographic distribution of living and Holocene coccolithophores in the Mediterranean Sea Marine Micropaleontology, 21 (1993), pp. 219-247

Knappertsbusch and Brummer, 1995

M. Knappertsbusch, G.-J.A. Brummer

A sediment trap investigation of sinking coccolithophores in the North Atlantic

Deep-Sea Research I, 42 (7) (1995), pp. 1083-1109

Kontoyiannis et al., 2005

H. Kontoyiannis, E. Balopoulos, O. Gotsis-Skretas, A. Pavlidou, G. Assimakopoulou, E.

Papageorgiou

The hydrology and biochemistry of the Cretan Straits (Antikithira and Kassos Straits) revisited in the period June 1997-May 1998

Journal of Marine Systems, 53 (2005), pp. 37-57

Malinverno et al., 2003a

E. Malinverno, C. Corselli, P. Ziveri, G. De Lange, A. Hübner

Coccolithophorid export production and fluxes in the Ionian Basin, eastern Mediterranean

M.V. Triantaphyllou (Ed.), Coccolithophores 2003, Gaia, Heraklion, Crete, Greece (2003), p. 64

Malinverno et al., 2003b

E. Malinverno, P. Ziveri, C. Corselli

Coccolithophorid distribution in the Ionian Sea and its relationship to eastern Mediterranean circulation during late fall to early winter 1997

Journal of Geophysical Research, 108 (C9) (2003), p. 8115

http://dx.doi.org/10.1029/2002JC001346

Malinverno et al., 2004

E. Malinverno et al.

Biogeochemical fluxes in the Ionian Sea (eastern Mediterranean) in relation to hydrographic conditions

Ocean Research Conference, Honolulu, Hawaii, USA (2004)

Malinverno et al., 2008

Malinverno, E., Dimiza, M.D., Triantaphyllou, M.V., Dermitzakis, M.D., Corselli, C., 2008. T $\alpha$

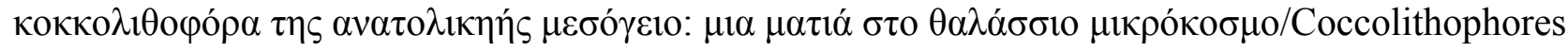
of the eastern Mediterranean Sea: a look into the marine microworld/I coccolitoforidi del Mar Mediterraneo orientale: uno sguardo nel microcosmo marino. ION Publications, Athens.

Malinverno et al., in preparation

Malinverno, E., Maffioli, P., Corselli, C., De Lange, G., in preparation. Present-day fluxes of coccolithophores and diatoms in the pelagic Ionian Sea. Marine Micropaleontology.

McIntyre and Bé, 1967

A. McIntyre, A.W.H. Bé

Modern coccolithophores of the Atlantic Ocean, I, Placoliths and cyrtoliths

Deep-Sea Research, 14 (1967), pp. 561-597 
Article | PDF (5745 K)Full Text via CrossRef

Milliman et al., 1999

J.D. Milliman, P.J. Troy, W.M. Balch, A.K. Adams, Y.-H. Li, F.T. Mackenzie

Biologically mediated dissolution of calcium carbonate above the chemical lysocline?

Deep Sea Research Part I: Oceanographic Research Papers, 46 (10) (1999), pp. 1653-1669

Article | PDF (300 K) | View Record in Scopus | Cited By in Scopus (186)

Molfino and McIntyre, 1990

B. Molfino, A. McIntyre

Precessional forcing of nutricline dynamics in the equatorial Atlantic

Science, 249 (1990), pp. 766-769

View Record in Scopus | Cited By in Scopus (155)

Molinaroli et al., 1993

E. Molinaroli, S. Guerzoni, G. Rampazzo

Contribution of Saharan dust to the Central Mediterranean Basin

Geological Society of America Special Paper, 284 (1993), pp. 303-312

Newton et al., 1994

P.P. Newton, R.S. Lampitt, T.D. Jickells, P. King, C. Boutle

Temporal and spatial variability of biogenic particle fluxes during JGOFS northeast Atlantic process studies at $47^{\circ} \mathrm{N} 20^{\circ} \mathrm{W}$

Deep-Sea Research, 41 (1994), pp. 1617-1642

Article | PDF (1770 K) | View Record in Scopus | Cited By in Scopus (130)

Nishida, 1979

S. Nishida

Atlas of Pacific nannoplanktons

News of Osaka Micropaleontologists, Special paper n., 3 (1979), pp. 1-31

Okada and Honjo, 1973

H. Okada, S. Honjo

The distribution of oceanic coccolithophorids in the Pacific

Deep-Sea Research, 20 (1973), pp. 355-374

Article | PDF (2050 K) | View Record in Scopus | Cited By in Scopus (208)

Okada and Matsuoka, 1996

H. Okada, M. Matsuoka

Lower-photic nannoflora as an indicator of the late Quaternary monsoonal palaeo-record in the tropical Indian Ocean

A. Moguilevsky, R. Whatley (Eds.), Microfossils and Ocean Environments, Aberystwyth Press, Aberystwyth (1996), pp. 232-245

Full Text via CrossRef

Okada and McIntyre, 1977

H. Okada, A. McIntyre

Modern coccolithophores of the Pacific and North Atlantic Oceans

Micropaleontology, 23 (1977), pp. 1-55

Full Text via CrossRef

Okada and McIntyre, 1979 
H. Okada, A. McIntyre

Seasonal distribution of modern coccolithophores in the western North Atlantic Ocean

Marine Biology, 54 (1979), pp. 319-328

View Record in Scopus | Full Text via CrossRef | Cited By in Scopus (140)

Psarra et al., 2000

S. Psarra, A. Tselepides, L. Ignatiades

Primary productivity in the oligotrophic Cretan Sea (NE Mediterranean): seasonal and interannual variability

Progress In Oceanography, 46 (2000), pp. 187-204

Article | PDF (3529 K) | View Record in Scopus | Full Text via CrossRef | Cited By in Scopus (94)

Reid, 1980

F.M.H. Reid

Coccolithophorids of the North Pacific Central Gyre with notes on their vertical and seasonal

distribution

Micropaleontology, 26 (1980), pp. 1-9

Rosteck et al., 1997

F. Rosteck, E. Bard, L. Beaufort, C. Sonzogni, G. Ganssen

Sea surface temperature and productivity records for the past $240 \mathrm{kyr}$ in the Arabian Sea

Deep-Sea Research II, 44 (1997), pp. 1461-1480

Sáez et al., 2003

A.G. Sáez et al.

Pseudo-cryptic speciation in coccolithophores

Proceedings of the National Academy of Science, 100 (12) (2003), pp. 7163-7168

Sprengel et al., 2000

C. Sprengel, K.-H. Baumann, S. Neuer

Seasonal and interannual variation of coccolithophore fluxes and species composition in sediment traps north of Gran Canaria $\left(29^{\circ} \mathrm{N} 15^{\circ} \mathrm{W}\right)$

Marine Micropaleontology, 39 (2000), pp. 157-178

Sprengel et al., 2002

C. Sprengel, K.-H. Baumann, J. Henderiks, R. Henrich, S. Neuer

Modern coccolithophore and carbonate sedimentation along a productivity gradient in the Canary

Islands region: seasonal export production and surface accumulation rates

Deep-Sea Research II, 49 (2002), pp. $\quad 3577-3598$

Stavrakakis et al., 2000

S. Stavrakakis, G. Chronis, A. Tselepides, S. Heussner, A. Monaco, A. Abassi

Downward fluxes of settling particles in the deep Cretan Sea (NE Mediterranean)

Progress in Oceanography, 46 (2000), pp. 217-240

Stoll et al., 2007

H.M. Stoll, A. Arevalos, A. Burke, P. Ziveri, G. Mortyn, N. Shimizu, D. Unger 
Seasonal cycles in biogenic production and export in Northern Bay of Bengal sediment traps Deep-Sea Research II, 54 (2007), pp. 558-580

Takahashi and Okada, 2000

K. Takahashi, H. Okada

Environmental control on the biogeography of modern coccolithophores in the southeastern Indian

Ocean offshore of Western Australia

Marine Micropaleontology, 39 (2000), pp. 73-86

Tanaka, 1991

Y. Tanaka

Calcareous nannoplankton thanatocoenoses in surface sediments from the seas around Japan

Science Reports of the Tohoku University Series, 2 (61) (1991), pp. 127-198

Triantaphyllou et al., 2002

M.V. Triantaphyllou, M. Dermizakis, M.D. Dimiza

Holo- and heterococcolithophores (calcarereous nannoplankton) in the gulf of Korthi (Andros island, Aegean Sea, Greece) during late summer 2001

Revue de Paleobiologie, 21 (1) (2002), pp. 353-369

Triantaphyllou et al., 2004

M.V. Triantaphyllou, P. Ziveri, A. Tselepides

Coccolithophore export production and response to seasonal surface water variability in the oligotrophic Cretan Sea (NE Mediterranean)

Micropaleontology, 50 (suppl. 1) (2004), pp. 127-144

Tselepides et al., 2000

A. Tselepides, V. Zervakis, T. Polychronaki, R. Danovaro, G. Chronis

Distribution of nutrients and particulate organic matter in relation to the prevailing hydrographic features of the Cretan Sea (NE Mediterranean)

Progress In Oceanography, 46 (2000), pp. 113-142

Weber-van Bosse, 1901

Weber-van Bosse, A., 1901. Études sur les algues de l'Archipel Malaisien. III. Note preliminaire sur les résultats algologiques de l'expédition du Siboga. Jar. Bot. Buitenz, 17(ser. 2): 126-141.

Winter, 1985

A. Winter

Distribution of living coccolithophores in the California Current System, southern California

Borderland

Marine Micropaleontology, 9 (1985), pp. 197-223

Winter et al., 1994

A. Winter, R.W. Jordan, P.H. Roth 
Biogeography of living coccolithophores in ocean waters

A. Winter, W.G. Siesser (Eds.), Coccolithophores, Cambridge University Press, New York (1994), pp. $161-178$

Yacobi et al., 1995

Y.Z. Yacobi, T. Zohari, N. Kress, A. Hecht, R.D. Robarts, M. Waiser, A.M. Wood, W.K.W. Li Chlorophyll distribution throughout the southeastern Mediterranean in relation to the physical structures of the water mass

Journal of Marine Systems, 6 (1995), pp. 179-189

Young, 1994

J.R. Young

Functions of coccoliths

A. Winter, W.G. Siesser (Eds.), Coccolithophores, Cambridge University Press, Cambridge (1994), pp. $63-82$

Full Text via CrossRef

Young et al., 2003

J.R. Young, M. Geisen, L. Cros, A. Kleijne, C. Sprengel, I. Probert, J.B. Østergaard

A guide to extant calcareous nannoplankton taxonomy

Journal of Nannoplankton Research, Special Issue, 1 (2003), pp. 1-125

Full Text via CrossRef

Ziveri and Thunell, 2000

P. Ziveri, R.C. Thunell

Coccolithophore export production in Guaymas Basin, Gulf of California: response to climate forcing

Deep-sea Research II, 47 (2000), pp. 2073-2100

Article | PDF (985 K) | View Record in Scopus | Cited By in Scopus (46)

Ziveri et al., 1995a

P. Ziveri, R.C. Thunell, D. Rio

Export production of coccolithophores in an upwelling region: results from San Pedro Basin, Southern California Borderlands

Marine Micropaleontology, 24 (1995), pp. 335-358

Article | PDF (2143 K) | View Record in Scopus | Cited By in Scopus (66)

Ziveri et al., 1995b

P. Ziveri, R.C. Thunell, D. Rio

Seasonal changes in coccolithophore densities in the Southern California Bight during 1991-1992

Deep-Sea Research I, 42 (1995), pp. 1881-1903

Article | PDF (4598 K) | View Record in Scopus | Cited By in Scopus (28)

Ziveri et al., 1999

P. Ziveri, J.R. Young, J.E. van Hinte

Coccolithophore export production and accumulation rates

Georesearch Forum, 5 (1999), pp. 41-56

View Record in Scopus | Cited By in Scopus (14)

Ziveri et al., 2000a 
P. Ziveri, A.T.C. Broerse, J.E. van Hinte, P. Westbroek, S. Honjo

The fate of coccoliths at $48^{\circ} \mathrm{N} 21^{\circ} \mathrm{W}$, northeast Atlantic

Deep-Sea Research II, 47 (2000), pp. 1853-1875

Ziveri et al., 2000b

P. Ziveri, A. Rutten, G. De Lange, J. Thomson, C. Corselli

Present-day coccolith fluxes recorded in central eastern Mediterranean sediment traps and surface sediments

Palaeogeography, Palaeoclimatology, Palaeoecology, 158 (2000), pp. 175-195

Ziveri et al., 2004

P. Ziveri, K.-H. Baumann, B. Böckel, J. Bollman, J.R. Young

Present day coccolithophore biogeography in the Atlantic Ocean

H.R. Thierstein, J.R. Young (Eds.), Coccolithophores: From Molecular Processes to Global impact, Springer Verlag (2004) 